\title{
Illite/smectite diagenesis and thermal evolution of Lower Cretaceous-Paleogene successions in the Dolna Kamchiya Depression, Eastern Bulgaria
}

\author{
Yavor Stefanov \\ Faculty of Geology and Geography, Department of Mineralogy, Petrology and Economic Geology, Sofia University \\ "St Kliment Ohridski”, 15 Tsar Osvoboditel Blvd,1504 Sofia; e-mail: yavor@gea.uni-sofia.bg
}

(Accepted in revised form: January 2018)

\begin{abstract}
The diagenesis of mixed-layer illite/smectite (I/S) minerals in Lower Cretaceous-Paleogene successions from the Dolna Kamchiya Depression was studied, using X-ray diffraction analysis of the clay fraction $(<2 \mu \mathrm{m})$ from core samples. The proportion of illite in I/S and degree of ordering increase with depth irrespective of the geological age, indicating that highly expandable I/S compositions were progressively illitized during the burial evolution. Lowest smectite values are recorded in the Lower Cretaceous deposits, whereas in the Paleogene sections are documented great regional variations in the I/S mineralogy, caused by differential basin subsidence. The transition from randomly interstratified (R0) to R1-ordered I/S occurs between depths of $2200 \mathrm{~m}$ and $2400 \mathrm{~m}$, and crosscuts the major stratigraphic boundaries. The variable patterns of I/S depth profiles resulted from the combined influence of temperature, burial history, sedimentation and subsidence rates, and basin geodynamic types on diagenesis. The rapid increase in illite content in the I/S clays across the main unconformities reflects the great thickness of eroded sediments during uplift and denudation events and/or elevated heat flow. The reconstructed palaeogeothermal gradient for the Eocene after corrections for decompaction and erosion would correspond to the values for foreland basin settings reported in the literature. Application of the I/S geothermometer to the Lower Cretaceous-Paleogene rocks demonstrates a general trend of increased organic maturity toward southeast in relatively isochronous deposits. The new results appear to be the first record for the effect of a multiphase basin evolution on the smectite illitization in sedimentary successions from the Dolna Kamchiya Depression.
\end{abstract}

Stefanov, Y. 2018. Illite/smectite diagenesis and thermal evolution of Lower Cretaceous-Paleogene successions in the Dolna Kamchiya Depression, Eastern Bulgaria. Geologica Balcanica, 47 (1), $3-21$.

Keywords: Mixed-layer illite/smectite minerals, I/S diagenesis, thermal evolution, organic maturity, Lower Cretaceous-Paleogene, Dolna Kamchiya Depression.

\section{INTRODUCTION}

Smectite (S) to illite (I) conversion is the main burialdiagenetic reaction in argillaceous rocks of sedimentary basins. This change is caused by the progressive increase in illite layers in mixed-layer I/S during burial (Burst, 1959, 1969; Perry and Hower, 1970; Hower et al., 1976; Lynch, 1997; and many others). The $\mathrm{S} \rightarrow \mathrm{I}$ transformation has been documented in burial diagenesis (Burst, 1959, 1969; Dunoyer de Segonzac, 1970; Perry and Hower, 1970; Weaver and Beck, 1971; Hower et al., 1976; Boles and Franks, 1979; Środoń, 1984a; Velde et al., 1986; Glasmann et al., 1989; Lindgreen, 1991; McCarty and Thompson, 1991; Velde and Vasseur, 1992; Pollastro, 1993; Hillier et al., 1995; Vara- jao and Meunier, 1995, 1996), hydrothermal alteration (Steiner, 1968; Jennings and Thompson, 1986), and contact metamorphism (Nadeau and Reynolds, 1981). The nature of smectite diagenesis or smectite illitization (Bethke and Altaner, 1986) has received considerable attention because of its potential of (1) flushing hydrocarbons from the shales (Burst, 1969; Bruce, 1984); (2) catalyzing hydrocarbon generation (Johns and Shimoyana, 1972); (3) producing high pore-fluid pressures (Powers, 1967; Magara, 1975); and (4) providing cementation agents to sandstones (Towe, 1962; Boles and Franks, 1979; Lahann, 1980). Overall, the chemical changes associated with this reaction include the uptake of aluminum and potassium and substitution for silica and hydrated, exchangeable cations (e.g., Na, 
$\mathrm{Mg}, \mathrm{Ca}, \mathrm{Fe}$, etc.), which carry the interlayer water in smectite lattice. The reaction occurs under increasing temperature during burial and is believed to be temperature dependant, provided enough $\mathrm{K}^{+}$is available (Perry and Hower, 1970; Hower et al., 1976; Velde and Iijima, 1988). The age of the rocks, or residence time at some temperature, has also been recognized as an important factor (Eberl and Hower, 1976; Velde and Espitalié, 1989). Despite the general agreement on the progressive nature of smectite illitization during burial diagenesis, some principal aspects of the reaction remain controversial. There are two end-member hypotheses regarding the exact mechanism. The first postulates that smectite transforms to illite as a solidstate transformation on an intact alumino-silicate lattice via series of interstratified phases (Reynolds and Hower, 1970; Bethke and Altaner, 1986). Alternatively, through TEM examination, smectite has been seen to convert to "fundamental" illite particles by either dissolution-(re)precipitation process (Boles and Franks, 1979; Nadeau et al., 1985; Ahn and Peacor, 1986; Dong et al., 1997) or Ostwald ripening (Morse and Casey, 1988; Eberl et al., 1990; Eberl, 1993). The duration of transformation has been estimated in several studies through mathematical models employing Arrhenius rate law expressions that describe the kinetics of this reaction (Pytte and Reynolds, 1989; Elliott et al., 1991; Velde and Vasseur, 1992; Huang et al., 1993; Elliott and Matisoff, 1996). Most importantly, the $\mathrm{S} \rightarrow \mathrm{I}$ conversion can serve as an independent geothermometer to constrain the proposed thermal history of a basin for better prediction of source rock maturation (Pytte and Reynolds, 1989; Pollastro, 1990, 1993; Elliot et al., 1991; Huang et al., 1993).

Lower Cretaceous-Paleogene successions from the Dolna Kamchiya Depression record multiphase basin evolution characterized by different heat flow regimes. The main objective of this article is description of the mineralogical composition of mixed-layer I/S from argillaceous rocks in order to establish variations in the I/S diagenesis as a function of various geological factors (i.e., burial depth, geothermal gradient, stratigraphy, uplifts, and erosion). A detailed study on the interstratified I/S provides the estimate of the experienced palaeotemperatures of the successions during a complex thermal history. Furthermore, the obtained results for the depths of critical I/S compositional changes (I/S geothermometer) have been correlated with the levels of organic maturity. Thus, the present study can be applicable to hydrocarbon exploration plays and to studies on diagenetic pathways in sandstones within the Dolna Kamchiya Depression.

\section{GEOLOGICAL BACKGROUND}

The Dolna Kamchiya Depression (DKD), or Kamchiya Sub-basin (Georgiev, 2012), is located in the coastal central parts of the Bulgarian Black Sea and extends offshore to the southeast into the Western Black sea basin (Fig. 1). In terms of its tectonic position, many controversial views have been proposed on the basis of available well and geophysical information. For example, in the early years of research, the area was considered as a part of a "transitional zone" between the Moesian Platform and the Fore-Balkan (Mandev, 1955; Bončev et al., 1957). Other authors claimed that the DKD is an individual structural unit superimposed on the southernmost periphery of the Moesian Platform and on the front of the Balkan thrust-fold belt (Atanasov, 1961, 1971; Bokov et al., 1987; Dachev et al., 1988; Georgiev, 2012). Alternative views were proposed by Bončev (1971), Karaguleva (1971) and Kânčev (1995), who opined that the DKD belongs to the northern strip of the Eastern Fore-Balkan, whereas Ivanov (1998), Vangelov (2002) and Bergerat et al. (2010) argued that it represents a fragment of the southernmost margin of the Moesian Platform.

The northern boundary of the DKD is outlined by the Bliznak fault zone (Atanasov and Georgiev, 1987), where it is in contact with the Avren step, while Georgiev (2012) claimed that the northern basin slope dips steeply through listric faults into the southern Moesian Platform margin.

The southern boundary of the DKD is delineated by tectonic structures, which are under discussion in terms of their location and kinematics. For example, Atanasov $(1961,1971)$ established a series of reverse faults, along which Upper Cretaceous-Paleogene rocks of the Byala anticline are thrust upon upper Eocene-Oligocene successions of the DKD. Also, this author stated that, in certain areas, the southern boundary is marked by unconformably overlying upper Eocene rocks on eroded Fore-Balkan folds. According to Kânčev (1995), the "Chudnite Skali dislocation" delimits the boundary, and thus a part of the DKD is buried under the East Balkan fold-thrust belt. On the contrary, Vangelov (2002) argued that the southern boundary could be traced along a series of normal faults with NW-SE direction. Later on, Georgiev (2012) interpreted the southern basin slope as thrust-folded ("buried Fore-Balkan unit of the Balkan thrust-fold belt") and noted that the basin basement is marked by an intra-middle Eocene (Illyrian) unconformity.

The western side of the basin is fault-bounded by the Venelin-Tolbuhin fault zone (Atanasov and Georgiev, 1987), or the Aksakovo-Danube fault zone (Georgiev, 2012). Eastwards, the DKD gradually deepens (up to $7000 \mathrm{~m}$ ) and expands offshore (60-70 km), with the major sedimentary-fill being represented by Oligocene and Neogene successions (Georgiev, 2012).

In terms of basin classification, the DKD has been interpreted as a fore-orogenic depression (Yaranov, 1960; Atanasov, 1961, 1971), foredeep basin (Doglioni et al., 1996; Banks, 1997; Tari et al., 1997), retroarc foreland (Sinclair, 1997; Harbury and Cohen, 1997), 


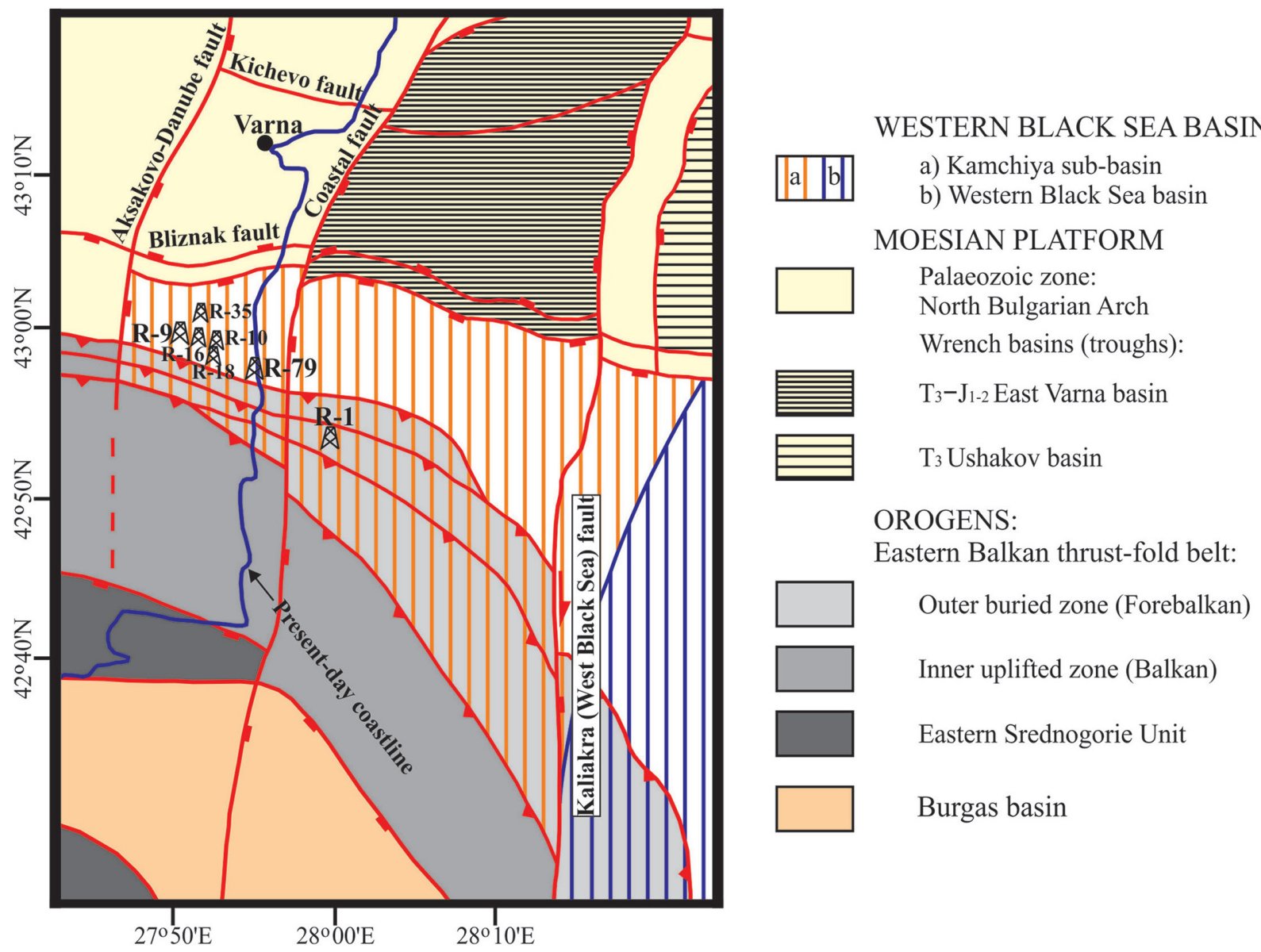

Fig. 1. Tectonic map of part of the western Black Sea (after Georgiev, 2012) with location of the wells studied.

or post-orogenic molasse basin (Vangelov, 2000). An alternative view was proposed by Georgiev (2012), who defined the Kamchiya sub-basin as a westwardwedging branch of the Western Black Sea Basin. According to Georgiev and Dabovski (2001), the initial formation of the sub-basin was coeval with the stacking of the Eastern Balkan thrust-belt during the middle Eocene. In addition, Georgiev (2012) claimed that the subsequent stages of basin evolution were controlled by the uplift and northward propagation of the Balkan thrust-fold belt, as well as by the opening and expansion of the Western Black Sea Basin.

\section{MATERIALS AND METHODS}

Basin-wide variations of the I/S mineralogy of the clay fraction $(<2 \mu \mathrm{m})$ were determined, using 46 core samples from seven wells across the basin (R-9 Staro Oryahovo, R-10 Novo Oryahovo, R-16 Novo Oryahovo, R-18 Novo Oryahovo, R-35 Novo Oryahovo, R-79 Shkorpilovtsi, and R-1 Samotino-sea). The location of these wells relative to the major tectonic features of the area is shown in Fig. 1. Samples were collected at different depths and cover a stratigraphic interval from the Lower Cretaceous to the upper Eocene. The lithostratigraphic subdivision of the well sections is based on detailed observations of the core and cutting material supplemented with interpretation of the wireline logs. The chronostratigraphical range of the units is defined on the basis of determined foraminiferal taxa by Juranov (1991) and calcareous nannofossils by Stoykova (1994).

The sampled shales were washed, crushed $(<2 \mathrm{~mm})$, and dispersed in distilled water, using an ultrasonic probe. The $<2 \mu \mathrm{m}$ clay fraction was separated by gravity settling. Calcite was removed by acetic acid buffered with sodium acetate $(\mathrm{pH} 4.5)$, and organic matter was eliminated by treatment with $30 \%$ solution of $\mathrm{H}_{2} \mathrm{O}_{2}$. Oriented slides of the $<2 \mu \mathrm{m}$ fraction were prepared by dispersing of dried powder sample ultrasonically in distilled water and pipetting the dispersion onto a glass slide, keeping the specimen thickness as constant as possible, with at least $3 \mathrm{mg}$ of clay per $\mathrm{cm}^{2}$ (Kisch, 1991). Ethylene-glycol solvation of all samples was carried out in a desiccator at $60{ }^{\circ} \mathrm{C}$ for over- 
night, a period adequate to obtain a glycol interlayer of maximum thickness. After glycolation, the samples were kept sealed in the desiccator until subjected to $\mathrm{X}$-ray diffraction (XRD) analysis. The XRD was performed using a TUR M62 diffractometer (Sofia University "St Kliment Ohridski") with filtered Co $\mathrm{K} \alpha$ radiation operating at $40 \mathrm{kV}$ and $45 \mathrm{~mA}$. Oriented airdried samples were scanned in the $4-80^{\circ} 2 \theta$ range at a scan speed of 2 seconds per step of $0.01^{\circ} 2 \theta$. Ethylene glycol (EG)-solvated samples were recorded under the same conditions as air-dried aggregates with a run interval of $4-50^{\circ} 2 \theta$.

The XRD patterns of air-dried and glycolated samples were compared to verify the presence of I/S. The expandability of mixed-layer I/S minerals was determined, following the procedures proposed by Reynolds and Hower (1970), Środoń (1980, 1981, 1984b), and Tomita et al. (1988). In most cases, however, methods used to measure the proportion of illite layers on the basis of computer modelling or pure I/S samples from bentonite (e.g., Reynolds and Hower, 1970; Środoń, 1980; Tomita et al., 1988) are not suitable to determine the illite content in mixed-layer I/S from shales, because these samples may contain discrete illite. To overcome this problem, Środoń (1981, 1984b) developed separate methods for random and ordered interstratifications, based on cross plots of selected diffraction peaks. In this study, depending on the XRD pattern of the samples, different techniques were applied, and the results were compared to obtain more detailed information illustrating the whole range of compositions of mixed-layer I/S minerals encountered in the Lower Cretaceous-Eocene successions.

\section{STRATIGRAPHIC AND REGIONAL VARIATIONS OF MIXED-LAYER ILLITE/ SMECTITE MINERALS IN THE DOLNA KAMCHIYA DEPRESSION}

Mixed-layer I/S minerals are the most common component in the studied shales from the DKD. Most samples are not pure I/S but contain small amounts of kaolinite and chlorite, the latter occurring only in samples from greater depths. Variable amounts of discrete illite are present, and they interfere with several XRD diffraction peaks of the mixed-layer I/S minerals.

The new results clearly illustrate systematic regional variations in the mixed-layer I/S depth trends, as the illite content increases with increasing burial depth and age, respectively (Table 1).

The lowest smectite content in I/S minerals was recorded in samples from the Lower Cretaceous successions in wells R-9 Staro Oryahovo and R-79 Shkorpilovtsi. The expandable smectite layers in these deposits rapidly decrease compared to the units above the Early Alpine unconformity/disconformity (Figs 2, $3)$. Thus, in both wells, the I/S composition remains fairly constant with less than $25 \%$ smectite layers, which indicates R1-ordered interstratifications. It is noteworthy that long-range ordering (R3) likely occurs at depths greater than $3300 \mathrm{~m}$ in well R-9 Staro Oryahovo, but this hypothesis should be tested after more detailed studies.

One sample from Cenomanian rocks of the Madara Formation in well R-9 Staro Oryahovo shows transition from random R0- to R1-ordered interstratifications with about 35\% smectite proportion in the mixed-layer I/S mineral (Fig. 2). This content greatly contrasts to the compositions in Lower Cretaceous strata of the same well, which is emphasized by a narrow depth interval of $200 \mathrm{~m}$. In well R-1 Samotino-sea, the smectite layers in I/S from Cenomanian shales are much lower ( $<15 \%$, Fig. 4$)$, but because of the supposedly allochtonous position of these rocks, their composition was not used in the reconstruction of the basin thermal history. However, a similar value of smectite content (20\%) was estimated in AlbianCenomanian deposits from well R-79 Shkorpilovtsi, which is solid evidence that, in the southern parts of the DKD, I/S minerals in these rocks occur with shortrange ordered (R1) interstratifications.

The most significant variations in the I/S compositions were recorded in samples from the Paleogene successions (i.e., Komarevo, Beloslav, Dvoynitsa, and Avren formations). In these cases, the proportion of expandable layers is well correlated with the thicknesses of the sections and the depths of burial, respectively (Figs 2, 3). For example, in well R-9 Staro Oryahovo, the total thickness of the mentioned lithostratigraphic units is about $1350 \mathrm{~m}$, which is much less than in the other two wells. Thus, in the Paleogene strata of this well, the smectite content of I/S varies between $48 \%$ and $63 \%$ and progressively decreases with increasing depth (Fig. 2). In the lowermost part of the Avren Formation, the I/S composition ranges from 58\% to $63 \%$ smectite, whereas downwards in the Dvoynitsa Formation this content decreases to $53-58 \%$ and to $48-50 \%$ in the sample from the Komarevo Formation, respectively. It should be noted that, in the other wells studied (R-10, R-16, R-18, and R-35 Novo Oryahovo), the proportions of smectite layers in the Paleogene rocks vary from $45 \%$ to $75-80 \%$ (Table 1 ). The latter values are considerably higher than estimated in the deposits from R-9 Staro Oryahovo and correlate with shallower depths of sampling. Therefore, in the axial part of DKD (i.e., Staro Oryahovo and Novo Oryahovo areas), the variations of I/S compositions in the Paleocene-Eocene section range from $45 \%$ to $80 \%$, thus corresponding to randomly ordered (R0) interstratifications, which is consistent with relatively moderate depths of burial.

The other two wells (R-79 Shkorpilovtsi and R-1 Samotino-sea) show a more variable I/S depth trend in the Paleogene successions compared to R-9 Staro Oryahovo (Figs 3, 4). For example, in the former well, the smectite content of I/S varies between 30\% and $68 \%$, as in the Avren Formation the proportions 
Table 1

Comparison of the proportion of smectite layers (\%) in the mixed-layer I/S minerals and type of ordering calculated by different methods. Note: The depths in brackets for the R-79 Shkorpilovtsi well are corrected depth intervals after inclination

\begin{tabular}{|c|c|c|c|c|c|c|}
\hline Depth & Formation/age & $\begin{array}{l}\text { Reynolds and } \\
\text { Hower (1970) }\end{array}$ & $\begin{array}{l}\text { Środoń } \\
\text { (1980) }\end{array}$ & $\begin{array}{c}\text { Środoń } \\
\text { (1981) }\end{array}$ & $\begin{array}{l}\text { Środoń } \\
\text { (1984) }\end{array}$ & $\begin{array}{l}\text { Tomita et } \\
\text { al. (1988) }\end{array}$ \\
\hline \multicolumn{7}{|c|}{ R-9 Staro Oryahovo } \\
\hline $1518.70 \mathrm{~m}$ & Avren Fm./Priabonian & $55 \%$; Rd & 74\%; Rd & $68 \%$ & & $60 \% ; \mathrm{R}=0$ \\
\hline $1604 \mathrm{~m}$ & Avren Fm./Priabonian & $55 \% ; \mathrm{Rd}$ & $56 \%$; Rd & $55 \%$ & & $\begin{array}{c}55-60 \% \\
\text { R=0 }\end{array}$ \\
\hline 1699 m & Dvoynitsa Fm./Lutetian & $60 \%$; Rd & $63 \% ; \mathrm{Rd}$ & $55 \%$ & & $\begin{array}{c}55-60 \% \\
R=0\end{array}$ \\
\hline $1769 \mathrm{~m}$ & Beloslav Fm./Ypresian & $55 \%$; Rd & $51 \% ; \mathrm{Rd}$ & $55 \%$ & & $\begin{array}{c}45-50 \% \\
\quad \mathrm{R}=0\end{array}$ \\
\hline $1818.80 \mathrm{~m}$ & Komarevo Fm./Thanetian & $45 \%$; Rd & 46\%; Rd & $52 \%$ & $50 \%$; Rd & $\begin{array}{c}35-37 \% \\
\mathrm{R}=0\end{array}$ \\
\hline $2409.30 \mathrm{~m}$ & Madara Fm./Cenomanian & 30\%; IM & $\begin{array}{l}\text { 44\%; } \\
\text { Rd-IS }\end{array}$ & & $42 \% ; \mathrm{Rd}-\mathrm{IS}$ & $\begin{array}{c}25-28 \% \\
\mathrm{R}=1\end{array}$ \\
\hline $2620 \mathrm{~m}$ & $\begin{array}{c}\text { Kamchiya Fm./Lower } \\
\text { Cretaceous }\end{array}$ & 15\%; IM & 22\%; IS & & $\begin{array}{l}16 \% ; \\
\text { IS-ISII }\end{array}$ & $25 \% ; \mathrm{R}=1$ \\
\hline $2896.50 \mathrm{~m}$ & $\begin{array}{c}\text { Kamchiya Fm./Lower } \\
\text { Cretaceous }\end{array}$ & 15-20\%; IM & $22 \%$; IS & & $15 \%$; ISII & $35 \% ; \mathrm{R}=1$ \\
\hline $3002 \mathrm{~m}$ & $\begin{array}{c}\text { Kamchiya Fm./Lower } \\
\text { Cretaceous }\end{array}$ & 15-20\%; IM & $22 \%$; IS & & 13\%; ISII & $\begin{array}{c}25-28 \% \\
R=1\end{array}$ \\
\hline $3187.40 \mathrm{~m}$ & $\begin{array}{c}\text { Kamchiya Fm./Lower } \\
\text { Cretaceous }\end{array}$ & 15\%; IM & 23\%; IS & & $\begin{array}{l}\text { 14-20\%; } \\
\text { IS-ISII }\end{array}$ & $\begin{array}{c}20-22 \% \\
\mathrm{R}=1\end{array}$ \\
\hline $3231.70 \mathrm{~m}$ & $\begin{array}{c}\text { Kamchiya Fm./Lower } \\
\text { Cretaceous }\end{array}$ & 15\%; IM & $20 \%$; IS & & 8-12\%; ISII & $\begin{array}{c}15 \% \\
\mathrm{R}=1-\mathrm{R}=2\end{array}$ \\
\hline $3325 \mathrm{~m}$ & Ticha Fm./Valanginian & 10-15\%; IM & 16\%; ISII & & & $10 \% ; \mathrm{R}=3$ \\
\hline \multicolumn{7}{|c|}{ R-10 Novo Oryahovo } \\
\hline $1582 \mathrm{~m}$ & Avren Fm./Priabonian & $80 \%$; Rd & $\begin{array}{l}59 \% ; \\
\text { Rd-IS }\end{array}$ & $72 \%$ & & $55 \% ; \mathrm{R}=0$ \\
\hline $1618 \mathrm{~m}$ & Avren Fm./Priabonian & 75\%; Rd & $60 \%$; Rd & $80 \%$ & & $60 \% ; \mathrm{R}=0$ \\
\hline $1795 \mathrm{~m}$ & Dvoynitsa Fm./Lutetian & $55 \%$; Rd & $59 \%$; Rd & $61 \%$ & & $\begin{array}{l}60-65 \% \\
\text { R=0 }\end{array}$ \\
\hline \multicolumn{7}{|c|}{ R-16 Novo Oryahovo } \\
\hline $895 \mathrm{~m}$ & Avren Fm./Priabonian & & $70 \%$; Rd & $80 \%$ & & $\begin{array}{c}70-73 \% \\
\text { R=0 }\end{array}$ \\
\hline $1415.50 \mathrm{~m}$ & Avren Fm./Priabonian & & $64 \%$; Rd & $69 \%$ & & $\begin{array}{c}58-60 \% \\
\mathrm{R}=0\end{array}$ \\
\hline $1563.20 \mathrm{~m}$ & Avren Fm./Priabonian & $65 \% ; \mathrm{Rd}$ & $50 \%$; Rd & $80 \%$ & & $60 \% ; \mathrm{R}=0$ \\
\hline $1633.30 \mathrm{~m}$ & Avren Fm./Priabonian & $55 \%$; Rd & $\begin{array}{l}54 \% ; \\
\text { Rd-IS }\end{array}$ & $70 \%$ & & $\begin{array}{c}50-55 \% ; \\
R=0\end{array}$ \\
\hline \multicolumn{7}{|c|}{ R-18 Novo Oryahovo } \\
\hline $1262.20 \mathrm{~m}$ & Avren Fm./Priabonian & 75\%; Rd & $72 \%$; Rd & $74 \%$ & & $\begin{array}{c}50-55 \% \\
\mathrm{R}=0\end{array}$ \\
\hline $1458 \mathrm{~m}$ & Avren Fm./Priabonian & $55 \%$; Rd & $\begin{array}{l}\text { 57\%; } \\
\text { Rd-IS }\end{array}$ & $56 \%$ & & $\begin{array}{c}55-58 \% \\
\mathrm{R}=0\end{array}$ \\
\hline $1707.50 \mathrm{~m}$ & Avren Fm./Priabonian & & $\begin{array}{l}51 \% ; \\
\text { Rd-IS }\end{array}$ & $70 \%$ & & $55 \% ; \mathrm{R}=0$ \\
\hline $1811 \mathrm{~m}$ & Avren Fm./Priabonian & $50 \% ; \mathrm{Rd}$ & $\begin{array}{l}48 \% ; \\
\text { Rd-IS }\end{array}$ & $72 \%$ & & $55 \% ; \mathrm{R}=0$ \\
\hline \multicolumn{7}{|c|}{ R-35 Novo Oryahovo } \\
\hline $1480 \mathrm{~m}$ & Avren Fm./Priabonian & $70 \%$; Rd & $52 \%$; Rd & $55 \%$ & & $45 \% ; \mathrm{R}=0$ \\
\hline $1585 \mathrm{~m}$ & Avren Fm./Priabonian & 70\%; Rd & $62 \%$; Rd & $68 \%$ & & $\begin{array}{c}70-73 \% \\
\mathrm{R}=0\end{array}$ \\
\hline
\end{tabular}


Table 1 (continued)

\begin{tabular}{|c|c|c|c|c|c|c|}
\hline Depth & Formation/age & $\begin{array}{l}\text { Reynolds and } \\
\text { Hower }(1970)\end{array}$ & $\begin{array}{l}\text { Środoń } \\
\text { (1980) }\end{array}$ & $\begin{array}{c}\text { Środoń } \\
\text { (1981) }\end{array}$ & $\begin{array}{c}\text { Środoń } \\
\text { (1984) }\end{array}$ & $\begin{array}{l}\text { Tomita et } \\
\text { al. (1988) }\end{array}$ \\
\hline $1740 \mathrm{~m}$ & Komarevo Fm./Thanetian & & $61 \%$; Rd & $50 \%$ & 44-48\%; Rd & $40 \% ; \mathrm{R}=0$ \\
\hline \multicolumn{7}{|c|}{ R-79 Shkorpilovtsi } \\
\hline $\begin{array}{c}957.50 \mathrm{~m} \\
(920 \mathrm{~m})\end{array}$ & Avren Fm./Priabonian** & & & $70 \%$ & & $\begin{array}{l}60-62 \% \\
\text { R=0 }\end{array}$ \\
\hline $\begin{array}{c}1139.50 \mathrm{~m} \\
(1085 \mathrm{~m})\end{array}$ & Avren Fm./Priabonian** & $60 \%$; Rd & $\begin{array}{l}53 \% ; \\
\text { Rd-IS }\end{array}$ & $60 \%$ & & $\begin{array}{l}55-60 \% \\
\text { R=0 }\end{array}$ \\
\hline $\begin{array}{c}1368.20 \mathrm{~m} \\
(1281 \mathrm{~m})\end{array}$ & Avren Fm./Priabonian** & 55-60\%; Rd & $\begin{array}{l}\text { 66\%; } \\
\text { Rd-IS }\end{array}$ & $58 \%$ & & \\
\hline $\begin{array}{l}1800.60 \mathrm{~m} \\
(1680 \mathrm{~m})\end{array}$ & Dvoynitsa Fm. & & $50 \%$; Rd & & & \\
\hline $\begin{array}{c}2080 \mathrm{~m} \\
(1926 \mathrm{~m})\end{array}$ & Dvoynitsa Fm. & $50 \%$; $\mathrm{Rd}$ & 42\%; IS & $44 \%$ & & $\begin{array}{c}50-53 \% \\
\mathrm{R}=0\end{array}$ \\
\hline $\begin{array}{c}2361 \mathrm{~m} \\
(2196 \mathrm{~m})\end{array}$ & Dvoynitsa Fm. & $30 \%$; IM & $33 \%$; IS & & 21-25\%; IS & $\begin{array}{l}30-32 \% \\
R=0-R=1\end{array}$ \\
\hline $\begin{array}{c}2449 \mathrm{~m} \\
(2284 \mathrm{~m})\end{array}$ & $\begin{array}{l}\text { sandstone fm/Albian(?) } \\
\text { - Cenomanian(?) }\end{array}$ & 20-30\%; IM & $22 \%$; IS & & $\begin{array}{l}17 \% ; \\
\text { IS-ISII }\end{array}$ & $\begin{array}{c}25-27 \% \\
R=1\end{array}$ \\
\hline $\begin{array}{c}2785.50 \mathrm{~m} \\
(2610 \mathrm{~m})\end{array}$ & $\begin{array}{c}\text { Kamchiya Fm./ } \\
\text { Barremian-Aptian** }\end{array}$ & 25\%; IM & 19\%; IS & & $\begin{array}{c}14 \% \\
\text { IS-ISII }\end{array}$ & $22 \% ; \mathrm{R}=1$ \\
\hline $\begin{array}{c}3065 \mathrm{~m} \\
(2880 \mathrm{~m}) \\
\end{array}$ & Kamchiya Fm./Barremian** & 10-12\%; IM & 16\%; IS & & 8-9\%; ISII & $\begin{array}{c}20 \% \\
\mathrm{R}=1-\mathrm{R}=2\end{array}$ \\
\hline $\begin{array}{l}3481.40 \mathrm{~m} \\
(3275 \mathrm{~m})\end{array}$ & $\begin{array}{l}\text { Kamchiya Fm./ } \\
\text { Valanginian** }\end{array}$ & 15\%; IM & $\begin{array}{c}17 \% \\
\text { IS-ISII }\end{array}$ & & $<10 \%$ & $\begin{array}{l}20-23 \% \\
R=1-R=2\end{array}$ \\
\hline \multicolumn{7}{|c|}{ R-1 Samotino-sea } \\
\hline $940 \mathrm{~m}$ & $\begin{array}{c}\text { Avren Fm./Priabonian* } \\
\text { Priabonian** }\end{array}$ & $70 \%$; Rd & $62 \%$; Rd & & & $\begin{array}{c}65-70 \% \\
R=0\end{array}$ \\
\hline $1204 \mathrm{~m}$ & $\begin{array}{l}\text { Avren Fm./middle Eocene* } \\
\text { Priabonian** }\end{array}$ & 75\%; Rd & $\begin{array}{l}56 \% \\
\text { Rd-IS }\end{array}$ & $81 \%$ & & \\
\hline $1604 \mathrm{~m}$ & $\begin{array}{l}\text { Avren Fm./middle Eocene* } \\
\text { Priabonian** }\end{array}$ & & $53 \%$; Rd & $71 \%$ & & $\begin{array}{c}53-55 \% \\
\mathrm{R}=0\end{array}$ \\
\hline $1981 \mathrm{~m}$ & $\begin{array}{c}\text { Dvoynitsa Fm./Ypresian* } \\
\text { Priabonian** }\end{array}$ & & $\begin{array}{l}47 \% ; \\
\text { Rd-IS }\end{array}$ & $78 \%$ & & $55 \% ; \mathrm{R}=0$ \\
\hline $2247 \mathrm{~m}$ & $\begin{array}{c}\text { Dvoynitsa Fm./Ypresian(?)* } \\
\text { middle Eocene** }\end{array}$ & 35\%; IM & 40\%; IS & & 24\%; IS & $\begin{array}{c}43-45 \% \\
\mathrm{R}=0\end{array}$ \\
\hline $3289 \mathrm{~m}$ & $\begin{array}{c}\text { Dvoynitsa Fm./Ypresian(?)* } \\
\text { Ypresian** }\end{array}$ & 20-25\%; IM & $33 \%$; IS & & $23 \%$; IS & $\begin{array}{l}30-32 \% \\
R=0-R=1\end{array}$ \\
\hline $3474 \mathrm{~m}$ & $\begin{array}{c}\text { Dvoynitsa Fm./Ypresian(?)* } \\
\text { Ypresian** }\end{array}$ & 20\%; IM & $30 \%$; IS & & $\begin{array}{l}\text { 14-20\%; } \\
\text { IS-ISII }\end{array}$ & $\begin{array}{c}25-27 \% \\
R=1\end{array}$ \\
\hline $3545 \mathrm{~m}$ & $\begin{array}{c}\text { Byala Fm./Thanetian* } \\
\text { Ypresian** }\end{array}$ & 10-12\%; IM & $26 \%$; IS & & 9\%; ISII & $27 \% ; \mathrm{R}=1$ \\
\hline $3612 \mathrm{~m}$ & $\begin{array}{c}\text { Byala Fm./Thanetian* } \\
\text { Cenomanian** }\end{array}$ & 10-15\%; IM & 19\%; ISII & & 8\%; ISII & $25 \% ; \mathrm{R}=1$ \\
\hline
\end{tabular}

* Biostratigraphic data from Juranov (1991); ** Biostratigraphic data from Stoykova (1994).

of expandable layers range in a narrow interval (60$68 \%$ ), whereas downwards in the Dvoynitsa Formation notably larger variations were recorded (30-60\% smectite). In particular, the great total thickness of Paleogene strata in well R-1 Samotino-sea (3250 m) predetermined the significant variations with depth of the I/S mineralogy (15-70\% smectite). In this context, the smectite proportion in the Avren Formation remains relatively constant (55-70\%), whereas the content of expandable layers in the Dvoynitsa Formation ranges from $15 \%$ to $50 \%$. In the same well, there is a pronounced linear trend of illitization throughout the Paleogene succession with little deviation from the pattern associated with a slight increase in illite layers across the Illyrian unconformity (Fig. 4). Thus, the estimated I/S compositions in both wells unambigu- 


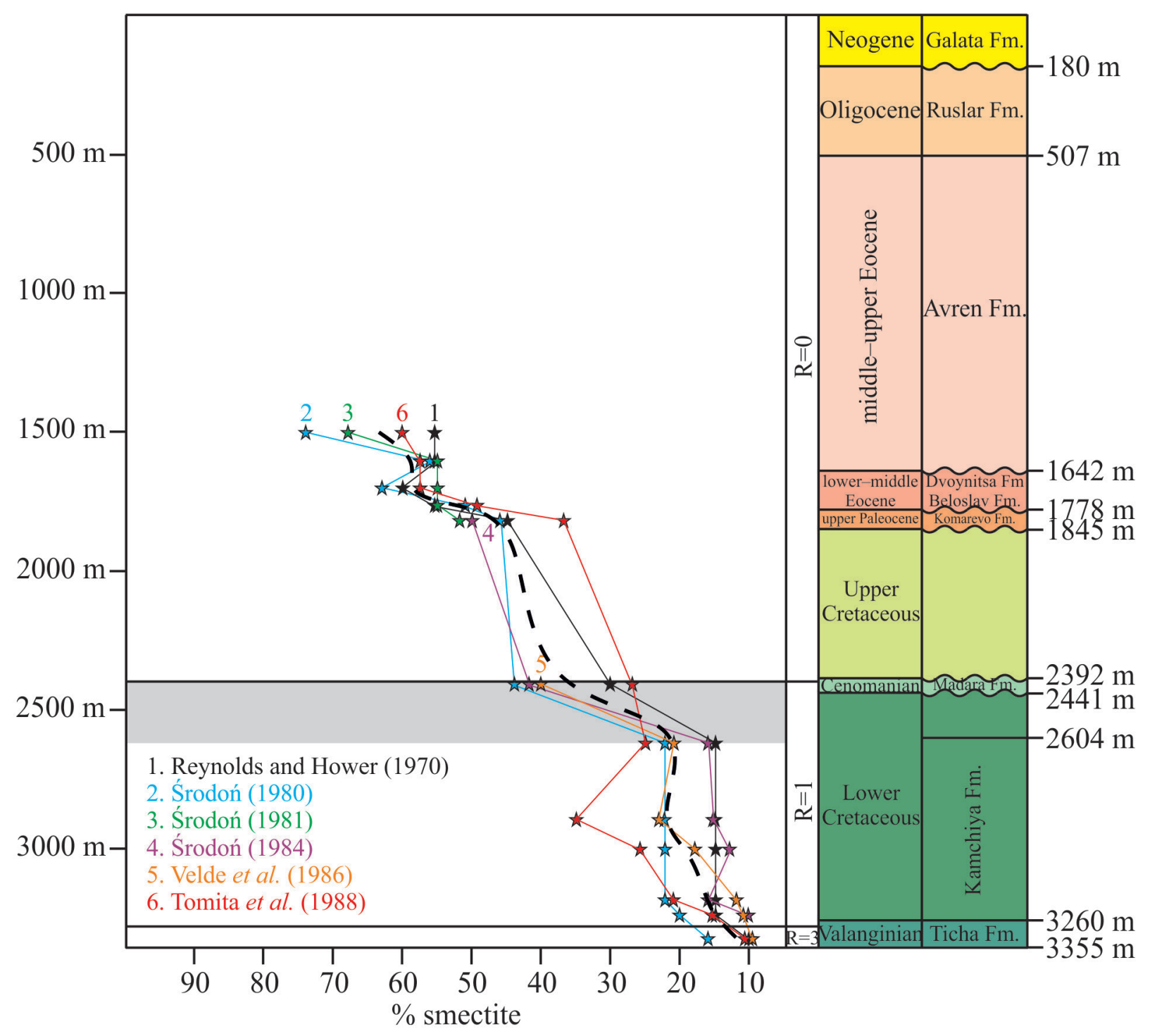

Fig. 2. Plot of present burial depths and stratigraphy versus percent (\%) smectite layers and ordering type in mixed-layer I/S from the Lower Cretaceous-Paleogene successions in the R-9 Staro Oryahovo well. Coloured solid lines show vertical variations of expandability estimated by different techniques. Dashed line approximates smectite-to-illite reaction profile. Note the rapid increase of illite layers in I/S within a narrow depth interval (shaded area).

ously indicate that the change from randomly ordered (R0) to R1-ordered interstratifications occurs within the Eocene section. In R-79 Shkorpilovtsi, this transition is recorded in the lowermost parts of the Dvoynitsa Formation (Fig. 3), whereas in R-1 Samotino-sea it is first documented in the uppermost levels of the same unit (Fig. 4). Moreover, the changes in ordering of the mixed-layer I/S across the study area occur within a narrow present-day subsurface depth interval (between $2200 \mathrm{~m}$ and $2400 \mathrm{~m}$ ), irrespective of the geological age. This characteristic is essential for interpretation of the thermal evolution of the basin and for evaluation of the stages and time of organic maturity, respectively.

\section{INTERPRETATION OF THE RESULTS AND DISCUSSION}

\section{Regional variations of the illite/smectite diagenesis in the Dolna Kamchiya Depression}

Analysis of the I/S compositions in the different lithostratigraphic units shows that the increasing illite content of mixed-layer I/S is a function of the burial depth, although this trend is generally not linear. Furthermore, the dependence on burial depth as a prime factor for the I/S diagenesis is indicated by the first appearance of R1-ordered interstratifications and the stratigraphic position of the main 


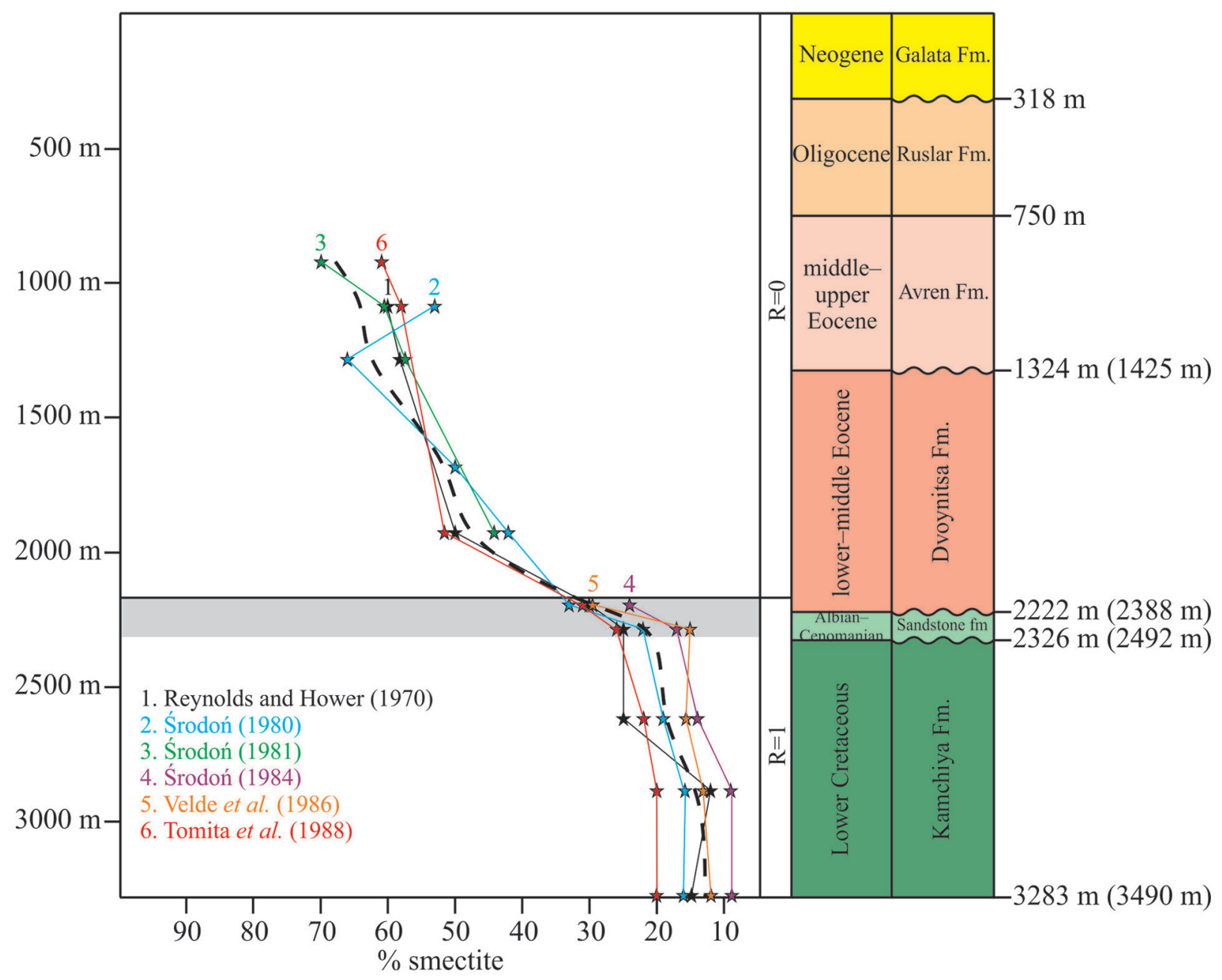

Fig. 3. Plot of present burial depths and stratigraphy versus percent (\%) smectite layers and ordering type in mixed-layer I/S from the Lower Cretaceous-Paleogene successions in the R-79 Shkorpilovtsi well. Coloured solid lines show vertical variations of expandability estimated by different techniques. Dashed line approximates smectite-to-illite reaction profile. Note the rapid increase of illite layers in I/S within a narrow depth interval (shaded area). Corrected depths after inclination and uncorrected depths (brackets) are shown on the right axis.

zone of ordering transition in a cross-section roughly parallel to the basin axis. In this direction (from R-9 Staro Oryahovo to R-1 Samotino-sea), the random to ordered I/S change occurs at relatively constant subsurface depths (2200-2400 m) and crosscuts the formation boundaries. Therefore, burial diagenesis, rather than geological time, was the main factor that controlled the increasing illite proportions of mixedlayer I/S.

Reconstruction of the palaeothermal conditions of Lower Cretaceous-Paleogene successions in the DKD is based on the approximate temperatures of recorded changes of the ordering types in I/S minerals (i.e., $\mathrm{R} 0 \rightarrow \mathrm{R} 1$ and $\mathrm{R} 1 \rightarrow \mathrm{R} 3$ ). In particular, several time-temperature models for these conversions have been proposed from studied basins of different geodynamic settings (e.g., Burst, 1969; Perry and Hower,
1970; Weaver and Beck, 1971; Hower et al., 1976; Hoffman and Hower, 1979; Dypvik, 1983; Środoń and Eberl, 1984; Burtner and Warner, 1986; Ramseyer and Boles, 1986; Velde et al., 1986; Pearson and Small, 1988; Freed and Peacor, 1989; Lindgreen, 1991; Pollastro, 1990, 1993; Abid et al., 2004; Libbey et al., 2013; Vazques et al., 2014). In this context, illitization of smectite in the mixed-layer I/S starts at about $50{ }^{\circ} \mathrm{C}$, the random to R1-ordered transition occurs near $100 \pm 20^{\circ} \mathrm{C}$, and long-range R3-ordering emerges at $175 \pm 5^{\circ} \mathrm{C}$.

Interpretation of the step-shaped I/S depth profile in well R-9 Staro Oryahovo (Fig. 5a) reveals two zones of rapid increase of the illite content in mixedlayer I/S, which correlates with major hiatuses in the section (i.e., Illyrian and Early Alpine unconformities). As previously discussed, ordered I/S appears 


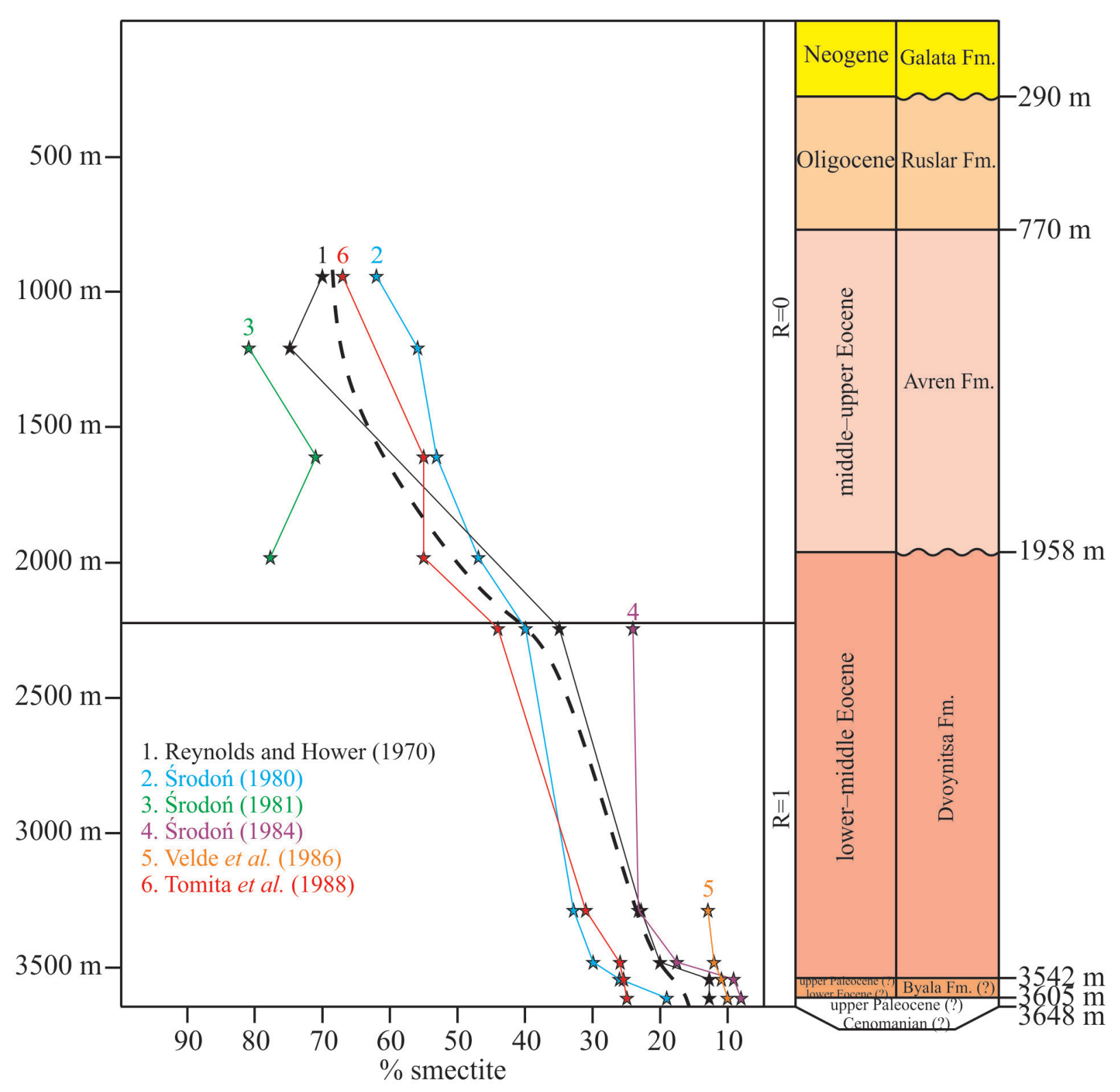

Fig. 4. Plot of present burial depths and stratigraphy versus percent (\%) smectite layers and ordering type in mixed-layer I/S from the Paleogene successions in R-1 Samotino-sea well. Coloured solid lines show vertical variations of expandability estimated by different techniques. Dashed line approximates smectite-to-illite reaction profile. Note the gradual increase of illite content in I/S with depth in contrast to wells R-9 and R-79.

first in the Cenomanian rocks of the Madara Formation (at about $2400 \mathrm{~m}$ ) and persists downwards with a relatively steady trend through the Lower Cretaceous strata (Fig. 5a). Therefore, this interval of stability of the short-range (R1) interstratifications unequivocally attests to maximum experienced burial palaeotemperatures ranging from $100{ }^{\circ} \mathrm{C}$ to $170{ }^{\circ} \mathrm{C}$. It should be noted, however, that these values considerably differ from the measured present-day subsurface temperatures at the inferred depths $\left(75-95{ }^{\circ} \mathrm{C}\right)$. Such great divergence in the temperatures probably reflects a large amount of denudation prior to deposition and subsidence in Late Cretaceous-Tertiary times followed by lowered geothermal gradient. Also, the rapid increase of illite percentage in I/S may have resulted from upward flow of deep, $\mathrm{K}^{+}$-bearing fluids along faults and/or lateral movement below unconformities (see Abid et al., 2004). The latest stage of smectite diagenesis (i.e., occurrence of R3-ordered I/S) is recorded in Valanginian rocks of the Ticha Formation below $3300 \mathrm{~m}$, which corresponds to maximum burial thermal effect at about $170{ }^{\circ} \mathrm{C}$ (Fig. 5a). In contrast, the samples from Paleocene-Eocene deposits contain only randomly interstratified I/S with relatively high 

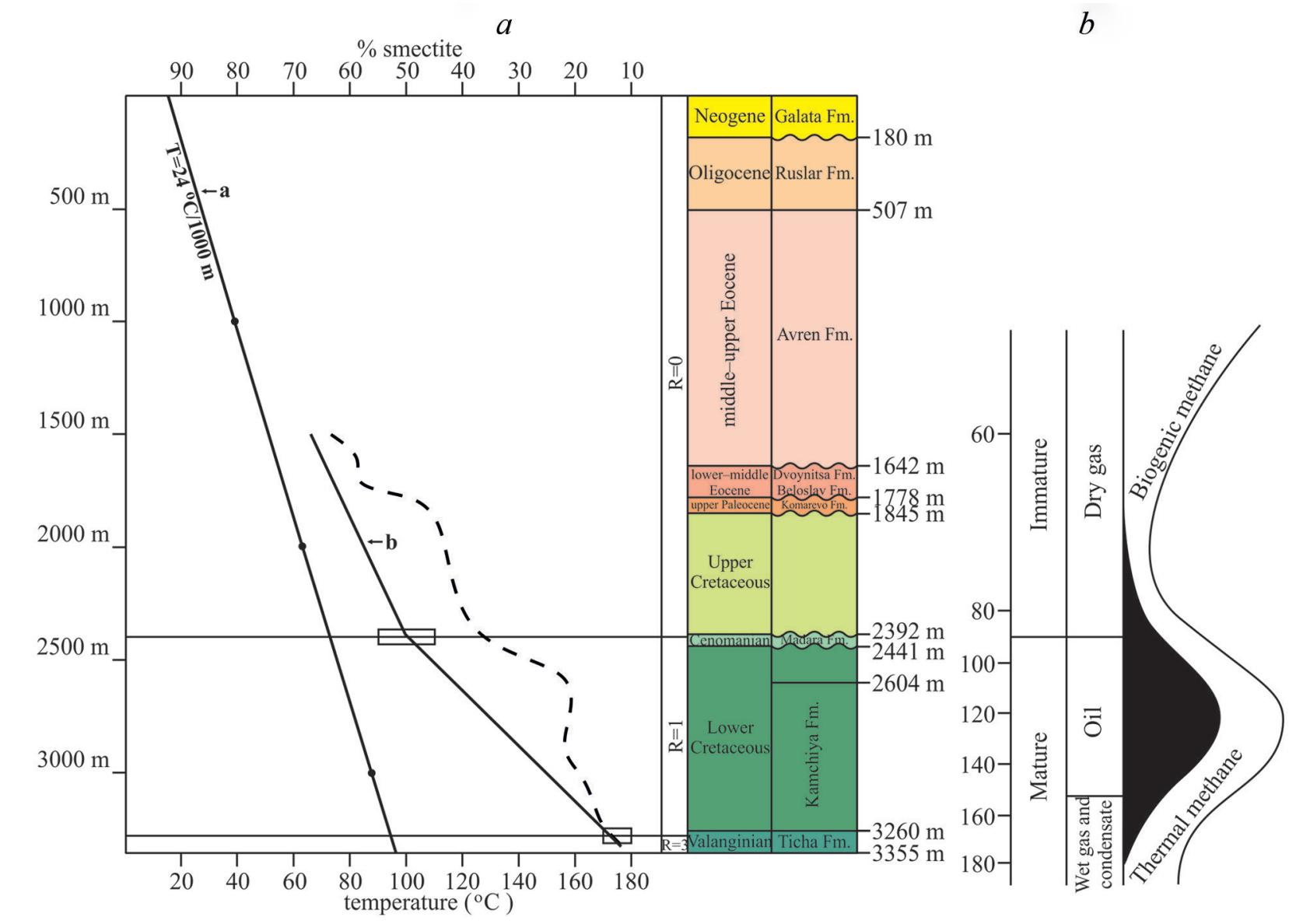

Fig. 5. a) Superimposed plots of depth and stratigraphy versus percent (\%) smectite layers (dashed line) and ordering type in mixed-layer I/S, and depth versus temperature in the R-9 Staro Oryahovo well. Bold lines indicate geothermal gradient at present burial depths (a) reconstructed temperatures at maximum burial (b). b) Generalized relationships between reconstructed palaeotemperatures and hydrocarbon generation stages in the Lower Cretaceous-Paleogene rocks from the R-9 Staro Oryahovo well.

expandability, and hence indicates palaeotemperatures between $60^{\circ} \mathrm{C}$ and $80^{\circ} \mathrm{C}$.

The reconstructed palaeothermal conditions in well R-79 Shkorpilovtsi are quite different from those estimated in well R-9 Staro Oryahovo. In particular, in the step-shaped curve pattern of illitization, the transition from random to R1-ordered I/S occurs in the lowermost part of the Dvoynitsa Formation (lower Eocene) at approximate depth of $2200 \mathrm{~m}$ (Fig. 6a). This is solid evidence that the Eocene successions reached maximum palaeotemperatures up to $100-110^{\circ} \mathrm{C}$, which are considerably higher than those estimated in the synchronous deposits of R-9 Staro Oryahovo. Comparison of the I/S trends throughout the Eocene section between both wells shows correlation of the palaeotemperatures in rocks of the Avren Formation $\left(60-75^{\circ} \mathrm{C}\right.$ ), while the results for rocks of the Dvoynitsa Formation reveal an elevated thermal effect $\left(75-110{ }^{\circ} \mathrm{C}\right)$. This discrepancy can be explained by the fact that, in the southern board of the DKD, the Dvoynitsa Formation has a great thickness $(1000-1500 \mathrm{~m})$, whereas north- wards it is reduced to $100-150 \mathrm{~m}$. In turn, the low proportions of expandable layers in the I/S minerals (less than 25\%) from Cenomanian and Lower Cretaceous strata in R-79 Shkorpilovtsi unambiguously indicate that these successions are in advanced stage of smectite diagenesis and have experienced maximum burial palaeotemperatures between $100^{\circ} \mathrm{C}$ and $160^{\circ} \mathrm{C}$ (Fig. 6a). It is noteworthy that the steady trend of illitization and estimated palaeotemperatures for the Cenomanian and Lower Cretaceous rocks in R-79 Shkorpilovtsi fully correlate with reconstructed thermal conditions for isochronous deposits in R-9 Staro Oryahovo. This fact suggests that the Lower Cretaceous successions in the DKD are products of a single basin system characterized by relatively constant parameters (water depth, sedimentation and subsidence rates, and heat flow).

The most peculiar differences are documented in well R-1 Samotino-sea, where the results indicate a progressive linear increase in the proportion of illite layers in $\mathrm{I} / \mathrm{S}$ with depth. In particular, the random to 


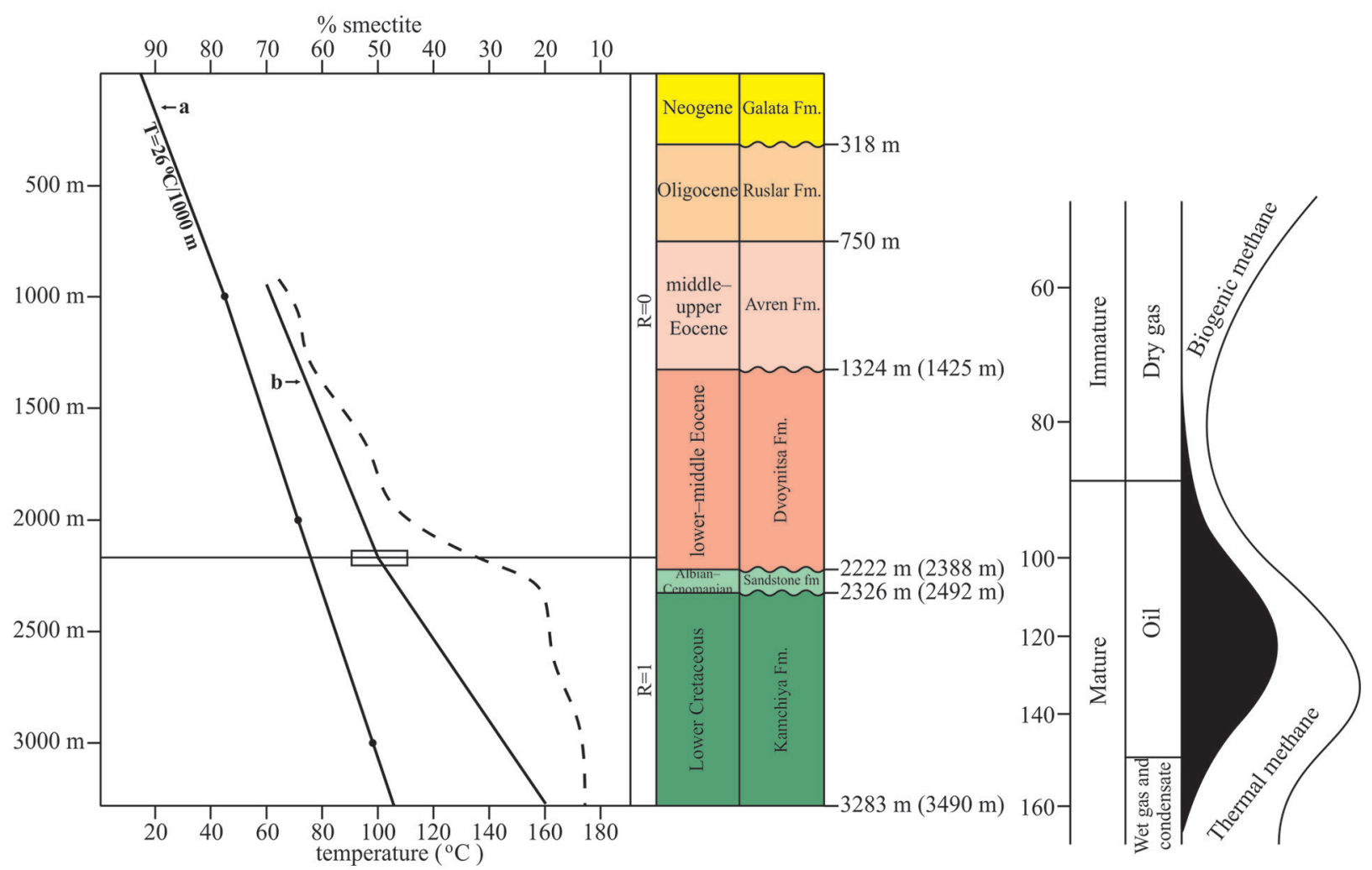

Fig. 6. a) Superimposed plots of depth and stratigraphy versus percent (\%) smectite layers (dashed line) and ordering type in mixed-layer I/S, and depth versus temperature in the R-79 Shkorpilovtsi well. Bold lines indicate geothermal gradient at present burial depths (a) and reconstructed temperatures at maximum burial (b). b) Generalized relationships between reconstructed palaeotemperatures and hydrocarbon generation stages in the Lower Cretaceous-Paleogene rocks from the R-79 Shkorpilovtsi well.

R1-ordered transition appears first at depth of about $2200 \mathrm{~m}$ in the uppermost parts of the Dvoynitsa Formation (Fig. 7a). Thus, only randomly (R0) interstratified I/S minerals are found in rocks of the Avren Formation, which corresponds to maximum burial palaeotemperatures between $60^{\circ} \mathrm{C}$ and $90^{\circ} \mathrm{C}$. Comparison of the latter values with those calculated for the same unit in the other two wells $\left(60-75^{\circ} \mathrm{C}\right)$ implies a relatively elevated upper temperature limit. This difference can be explained by the fact that, in the offshore part of the DKD, the thickness of the Avren Formation reaches more than $1000 \mathrm{~m}$, which was predetermined by greater rates of total basin subsidence. In turn, the most significant differences in the palaeothermal evolution related to Eocene successions in the entire DKD are recorded in the Dvoynitsa Formation. In this case, there is a distinct steady trend of illitization with notably decreased content of expandable smectite layers compared to the synchronous deposits in the other wells. Therefore, offshore in the southern board of the DKD, the rocks of the Dvoynitsa Formation experienced burial palaeotemperatures between $100{ }^{\circ} \mathrm{C}$ and
150-160 ${ }^{\circ} \mathrm{C}$ (Fig. $7 a$ ), which contrasts to the reconstructed thermal effect in the successions from R-9 Staro Oryahovo and R-79 Shkorpilovtsi. Regional variations in the palaeothermal evolution of lowermiddle Eocene successions throughout the DKD were likely caused by differential basin subsidence rates, particularly in the southern board of the basin, which was largely affected by a northward propagation of the Balkan thrust-fold belt. This general conclusion further supports the formation of a foredeep basin in late Paleocene-middle Eocene times, as originally suggested by Vangelov (2000).

\section{Implications for evaluation of organic maturity}

The I/S geothermometer provides maximum burial temperatures relative to the basin history that can be used as a maturation indicator for hydrocarbon generation (Pollastro, 1993, and references therein). In this context, a general relationship has been established between the changes of I/S and the main stages of organic maturity (Hoffman and Hower, 1979; Waples, 

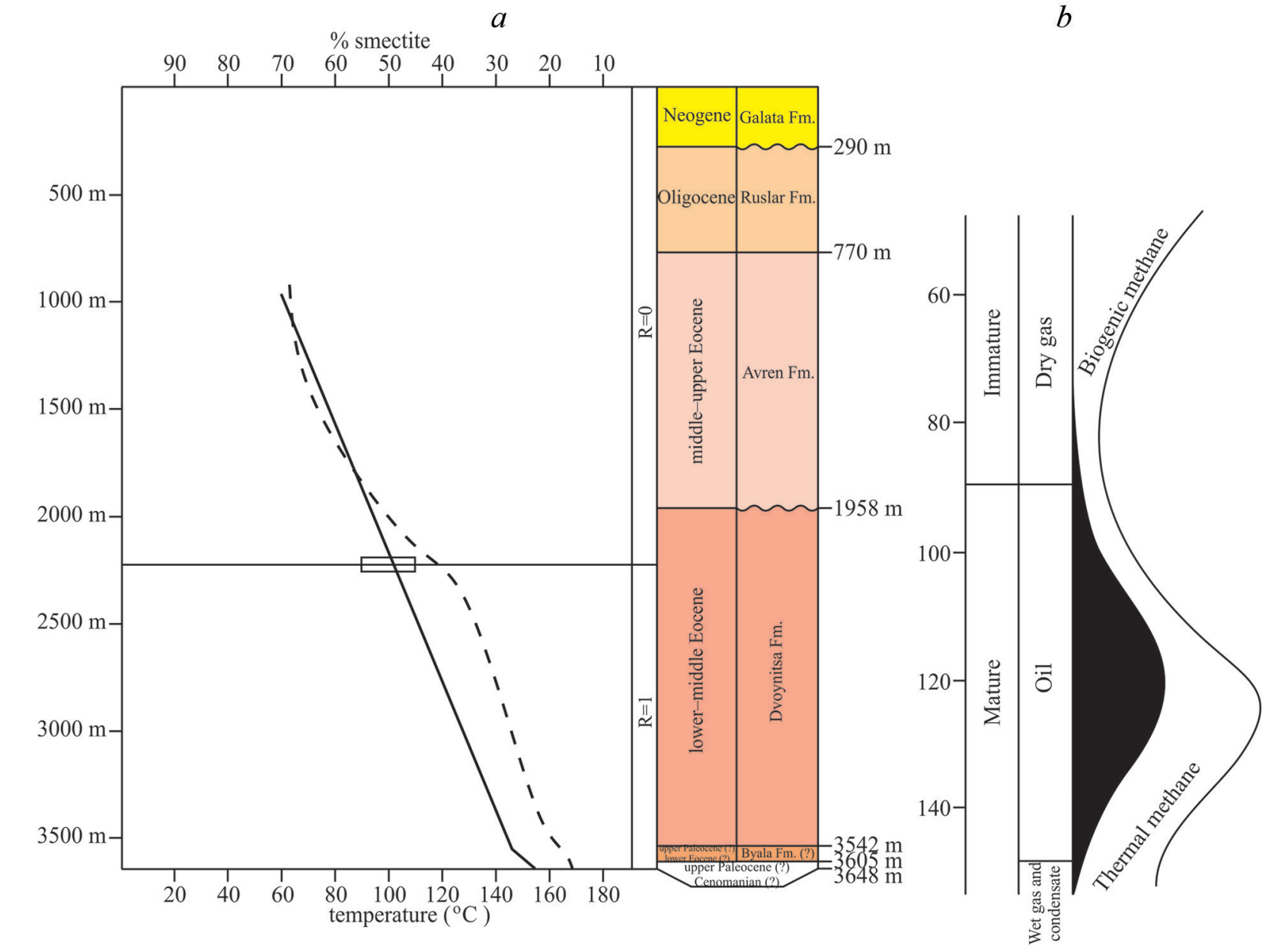

Fig. 7. a) Superimposed plots of depth and stratigraphy versus percent (\%) smectite layers (dashed line) and ordering type in mixed-layer I/S, and depth versus temperature in the R-1 Samotino-sea well. Bold line indicates reconstructed temperatures at maximum burial. b) Generalized relationships between reconstructed palaeotemperatures and hydrocarbon generation stages in the Paleogene rocks from the R-1 Samotino-sea well.

1980; Rice and Claypool, 1981; Tissot and Welte, 1984; Burtner and Warner, 1986; and many others). For example, the temperature range of $100-110^{\circ} \mathrm{C}$ for the ordering change of I/S from randomly interstratified (R0) to R1 approximates temperatures for the onset of peak oil generation zone, while conversion from R1 to long-range ordered (R3) roughly coincides with the upper limit of oil generation.

In this case, the identified regional variations in I/S diagenesis and the reconstructed maximum palaeotemperatures experienced in the Lower CretaceousPaleogene successions of the DKD are applicable to interpretation of the main stages of organic maturity. The actuality of the present study is emphasized by the fact that gas and condensate have been discovered in many wells within Paleogene sandstone reservoirs, although published results about genetic correlations and hydrocarbon source estimations are scarce (see Georgiev, 2012).
The calculated palaeotemperatures in the section of well R-9 Staro Oryahovo imply that, in the central part of the DKD, the Lower Cretaceous deposits were buried at temperatures $>100-110^{\circ} \mathrm{C}$, and therefore are thermally mature with respect to hydrocarbon generation. In comparison, the Upper Cretaceous-Paleogene rocks have never been affected by thermal conditions required for conversion of randomly interstratified I/S to ordered $\mathrm{I} / \mathrm{S}$, i.e., the onset of main generation zone (Fig. 5b). Moreover, such an assumption is indirect evidence for the origin of the condensate within Paleogene reservoirs, and namely, this accumulation has resulted from migration from source rocks older than Late Cretaceous. The application of the I/S geothermometer to the deposits of well R-79 Shkorpilovtsi suggests that the Lower Cretaceous-Cenomanian rocks and the lowermost part of the Dvoynitsa Formation experienced palaeotemperatures adequate for generation of thermal hydrocarbons if requisite organ- 
ic matter was present (Fig. 6b). The palaeotemperature values in the successions of well R-1 Samotino-sea indicate that the upper Eocene-Oligocene rocks are immature to marginally mature downwards (in the lowermost part of the Avren Formation), whereas organic matter in the fine-grained deposits of the Dvoynitsa Formation has attained a thermal maturity appropriate for hydrocarbon generation (Fig. 7b). The latter conclusion further supports the genetic correlations between the Samotino-sea condensate accumulation and molecular biomarkers from the Upper Cretaceouslower Eocene source rocks, as suggested by Georgiev (2012).

The inferred regional variations in the I/S diagenesis and the application of the I/S geothermometer to the Lower Cretaceous-Eocene successions demonstrate that, toward the east-southeast within the DKD (i.e., onshore $\rightarrow$ offshore) there is a well-pronounced trend of increased levels of organic maturity in the relatively contemporaneous deposits. Furthermore, in the same direction, younger stratigraphic intervals are found within the main hydrocarbon generation zone, which in turn were largely predetermined by differential basin subsidence during the Eocene and subsequent expansion of the Western Black Sea Basin.

\section{Reconstruction of the thermal evolution of the Lower Cretaceous-Paleogene successions in the Dolna Kamchiya Depression}

In the external zones of fold-and-thrust belts, and particularly in basins characterized by highly variable subsidence rates, such as syn-orogenic basins, it is difficult to discriminate between various factors that affect thermal maturity due to either tectonic or sedimentary burial. In this case, it is realistic to assume that the I/S diagenesis and experienced maximum palaeotemperatures of the studied successions in the DKD were primarily controlled by both geodynamic types and subsidence rates of the Early Cretaceous-Paleogene basins, as well as by the volume of eroded sediment piles during major hiatuses. In terms of the former, it is believed that there is a correlation between the geodynamic basin regime and the distribution of heat flow (see Allen and Allen, 2013, and references therein). Interpretation of the burial and thermal history requires decompaction corrections, modelling of tectonic subsidence, age constrain of the durations of hiatuses and the relative amount of eroded sediment column, variations of the heat flow through basin evolution, other complementary data from porosity-depth parameters for the main lithologies, and palaeobathymetric corrections. Since these techniques were not implemented in the present study, only implications regarding the reconstruction of the total basin subsidence and comparison with the estimated palaeotemperatures can be made on the basis of the I/S depth trends.

The pattern of I/S profiles in the well sections clearly helps to identify some significant differences in the subsidence rates throughout the DKD and the duration of hiatuses, respectively. Firstly, the well-pronounced contrast in the total subsidence curves recorded in the lower-middle Eocene successions of the Dvoynitsa Formation should be noted (Figs 8-10). However, the inferred spatial variations of the total basin subsidence match with the illitization trend through the section of the Dvoynitsa Formation. These facts unambiguously indicate that, during the Ypresian and Lutetian, the basin was characterized by variable subsidence rates, and the highest burial rate, in particular, occurred on the south-southeastern side. The latter conclusion is in accordance with the basin evolution outlined by Vangelov (2000), which was related to northward propagation of the Eastern Balkan thrust belt front onto the platform margin and resulted in the formation of an asymmetric foredeep basin with steep southern board. In contrast, comparisons between the trends of the total subsidence curves and the patterns of I/S profiles in the Avren Formation and the Lower Cretaceous rocks do not reveal significant differences in the burial histories throughout the present-day DKD, which in turn brings evidence that these successions were deposited in basins affected by relatively steady regional subsidence rates.

Another important feature that should be noted is the well-defined correlation between the duration of hiatuses, the changes of expandability, and the experienced maximum thermal effects. These relationships are well illustrated by the rapid decrease of smectite layers in the I/S minerals and by the higher burial palaeotemperatures below the Early Alpine unconformity in the Lower Cretaceous rocks of wells R-9 Staro Oryahovo (Fig. 8) and R-79 Shkorpilovtsi (Fig. 9). Such trends may be attributed to great thicknesses of the eroded sediment pile during a long-term Early Alpine non-deposition event and/or to changes in the geodynamic setting and basin systems. In turn, the analysis of the I/S curve and the estimated maximum burial palaeotemperatures in well R-1 Samotino-sea indicate that the thermal evolution below the Illyrian unconformity (i.e., in Ypresian and Lutetian times) in the southernmost periphery of the DKD was primarily controlled by the steady high rates of basin subsidence (Fig. 10).

The precise calculation of the palaeogeothermal gradient requires numerical simulation of the sedimentary basin by integrating factors that control temperatures (e.g., deposition, non-deposition, and erosion; heat flow history; thermal conductivity, heat capacity, and compaction parameters) and by calibrating with thermal indicators. Since such burial and thermal quantifications were not implemented in the present study, the resulting model must be considered as an approximation to the real basin history. In particular, the application of I/S geothermometer to deposits of the Dvoynitsa and Avren formations in wells R-79 Shkorpilovtsi and R-1 Samotino-sea enables reconstruction of the geothermal gradient during 


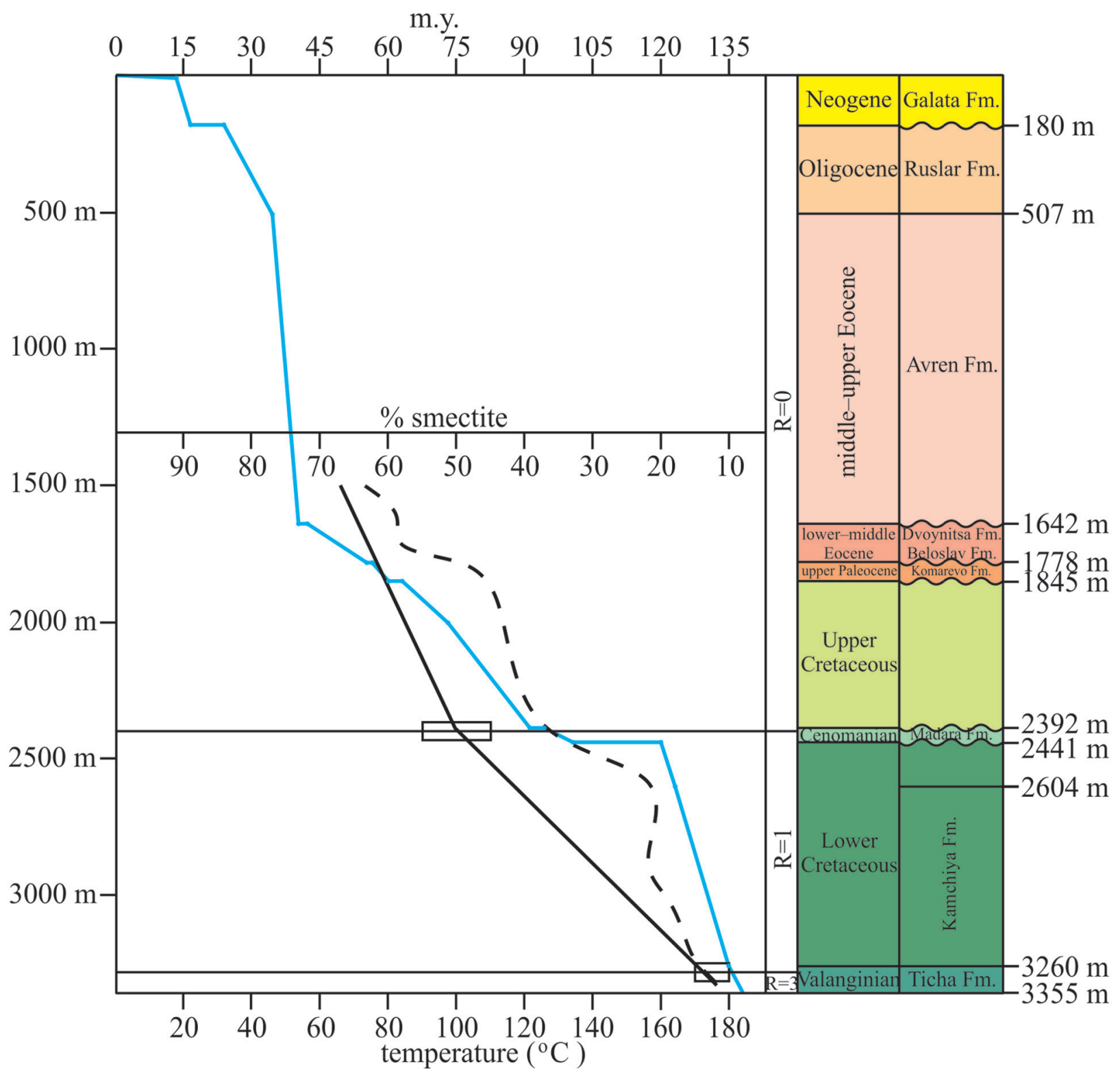

Fig. 8. Superimposed plot showing relationships between I/S profiles (dashed line), reconstructed temperatures (bold line), and total subsidence curve (blue line) in the R-9 Staro Oryahovo well. Note parallel trends in the changes of expandability and total basin subsidence.

the Eocene. Thus, the estimated palaeotemperatures at inferred burial depths (Figs 6, 7) indicate that the geothermal gradient was probably within $33-35^{\circ} \mathrm{C} / \mathrm{km}$, which is largely different from the measured modern geothermal gradient in the region $\left(24-26^{\circ} \mathrm{C} / \mathrm{km}\right)$. It should be noted that, after corrections for decompaction and erosion, these values would be reduced and would correspond to reported geothermal gradients for a foreland basin setting (Jacob and Kuckelkorn, 1977; Rybach and Bodmer, 1980; Rybach, 1984; Teichmüller and Teichmüller, 1986; Schegg, 1994; Schegg and Leu, 1996). In contrast, the palaeotemperature trend through the Lower Cretaceous-Cenomanian section in wells R-9 Staro Oryahovo and R-79 Shkorpilovtsi implies an elevated palaeogeothermal gradient of $60-70{ }^{\circ} \mathrm{C} / \mathrm{km}$. These extremely high values can be attributed to (1) different geodynamic stages of basin evolution; (2) increased heat flow typical for hyperthermal basins; and (3) great thickness of the eroded sedimentary pile. Alternatively, several studies have demonstrated that variations in the geothermal gradient commonly indicate changes in the heat conductivity of the sections, where poorly conductive shale formations are characterized by high geothermal gradient and heat flow (e.g., Robert, 1988; Pollack and Cercone, 1994; Cercone et al., 1996; Uysal et al., 2000). 


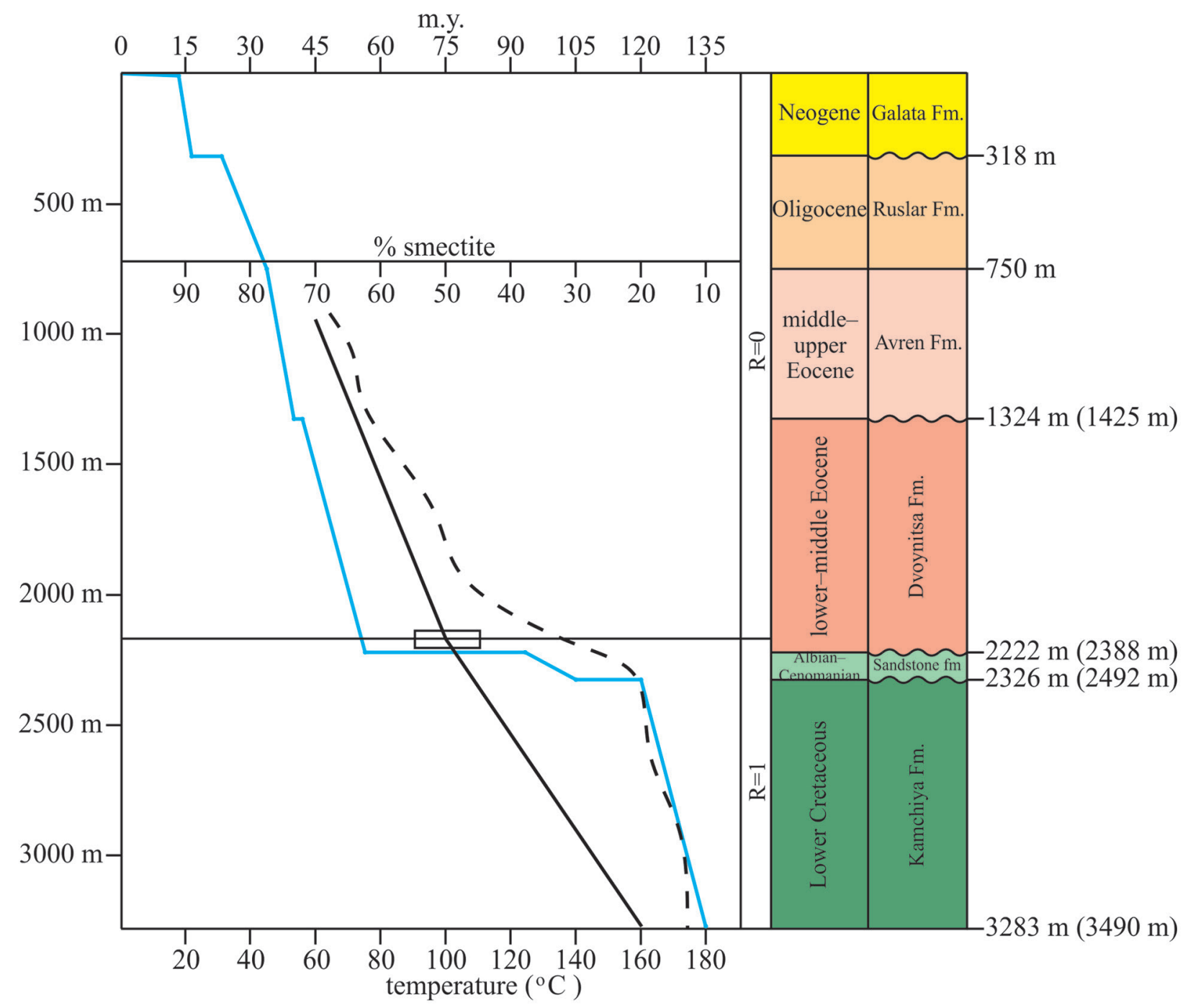

Fig. 9. Superimposed plot showing relationships between I/S profiles (dashed line), reconstructed temperatures (bold line), and total subsidence curve (blue line) in the R-79 Shkorpilovtsi well. Note parallel trends in the changes of expandability and total basin subsidence.

In this context, the Lower Cretaceous successions in the DKD are largely dominated by fine-grained sediments acting as a barrier to the vertical heat transfer, and it is therefore reasonable to conclude that the recorded variations in the geothermal gradient may have been controlled by different rock conductivities.

\section{CONCLUSIONS}

The compositional changes of I/S mixed-layer minerals reflecting the palaeothermal conditions during burial diagenesis have been identified throughout Lower Cretaceous-Paleogene successions in the Dolna Kamchiya Depression. In general, the proportion of illite layers and ordering types increase with depth in all wells and individual stratigraphic units.
In addition, the I/S depth profiles display important geographic variations on a regional scale. The lowest content of expandable smectite layers $(<25 \%)$ is constantly recorded in the Lower Cretaceous strata, while the most significant spatial variations are documented in lower-middle Eocene rocks of the Dvoynitsa Formation. This fact suggests that the I/S diagenesis and the thermal evolution of these successions were primarily controlled by the differential basin subsidence, which occurred in Ypresian and Lutetian times, and further supports the interpreted foredeep basin setting. In turn, the rapid increase of illite percentages across the major unconformities probably reflects large amounts of eroded sediments during uplift/ denudation events and/or higher palaeogeothermal gradients. In this context, the well-pronounced trend of abrupt compositional changes in the I/S mineral- 


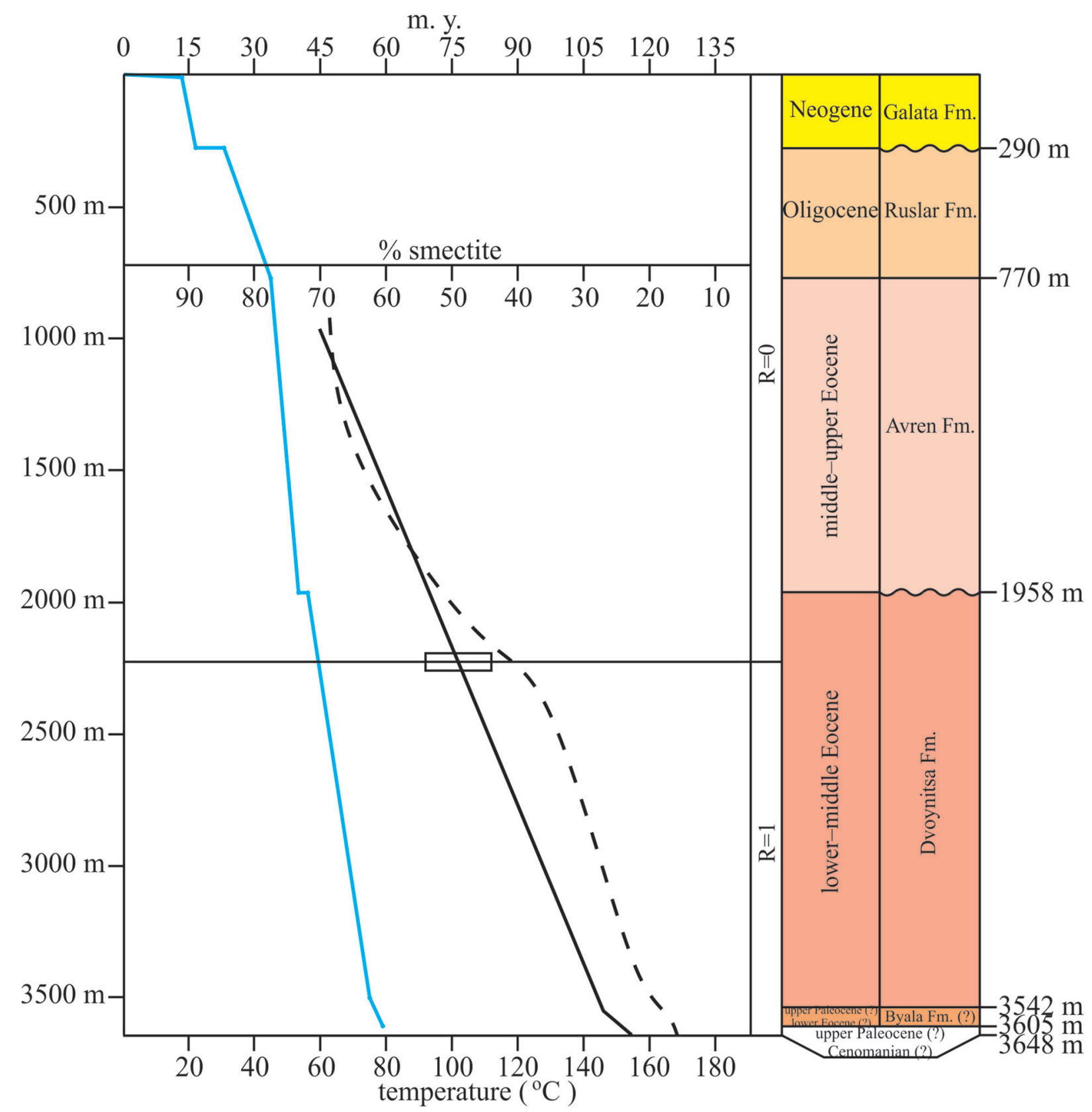

Fig. 10. Superimposed plot showing relationships between I/S profiles (dashed line), reconstructed temperatures (bold line), and total subsidence curve (blue line) in the R-1 Samotino-sea well.

ogy across the Early Alpine unconformity implies great thickness of an eroded section or, alternatively, elevated palaeogeothermal gradient. Also, the experienced maximum burial palaeotemperatures in the Eocene successions indicate that the palaeogeothermal gradient was probably $33-35{ }^{\circ} \mathrm{C} / \mathrm{km}$, but after corrections for decompaction and erosion it would correspond to values typical for hypothermal foreland basins. The application of the I/S geothermometer to the Lower Cretaceous-Paleogene section demonstrates a general trend of increased organic matu- rity in east-southeast direction within the present-day Dolna Kamchiya Depression. Thus, the Lower Cretaceous deposits onshore are thermally mature with respect to hydrocarbon generation, while offshore the onset of the main generation zone is found in the uppermost part of the Dvoynitsa Formation. The new results about I/S diagenesis and reconstructed palaeothermal evolution can be integrated in future basin modelling studies and, particularly, can be applied for evaluation of the hydrocarbon potential of the Dolna Kamchiya Depression. 


\section{Acknowledgements}

The author thanks G. Georgiev and D. Vangelov (Sofia University "St Kliment Ohridski”) for important discussions on the topic. I am indebted to D. Sinnyovsky (University of Mining and Geology "St Ivan Rilski") for providing information on the biostratigraphy. The analytical work of D. Sinnyo- vska (University of Mining and Geology "St Ivan Rilski") and V. Nakova (Sofia University "St Kliment Ohridski”) is also greatly acknowledged. This study was financially supported by Aurelian Oil and Gas plc. The author is grateful to Athanas Chatalov (Sofia University “St Kliment Ohridski”) for his critical review of the manuscript and helpful suggestions.

\section{REFERENCES}

Abid, I.A., Hesse, R., Harper, J.D. 2004. Variations in mixed layer illite/smectite diagenesis in the rift and post-rift sediments of Jeanne d'Arc Basin, Grand Banks offshore, Newfoundland, Canada. Canadian Journal of Earth Sciences 41, 401-429.

Ahn, J.H., Peacor, D.R. 1986. Transmission and analytical electron microscopy of the smectite-to-illite transition. Clays and Clay Minerals 34, 165-179.

Allen, P.A., Allen, J.R. 2013. Basin Analysis: Principles and Application to Petroleum Play Assessment ( $3^{\text {rd }}$ Edition). Wiley-Blackwell, Oxford, 632 pp.

Atanasov, A. 1961. Geology of the coastal part of the Forebalkan and the Kamchiya River valley. Travaux sur la Géologie de Bulgarie, Série Stratigraphie et Tectonique 2, 99-157 (in Bulgarian, with Russian and French abstracts).

Atanasov, A. 1971. Lower Kamchiya Foredeep. In: Yovchev, Y. (Ed.), Tectonic setting of Bulgaria. Tehnika, Sofia, 170-171 (in Bulgarian, with English abstract).

Atanasov, A., Georgiev, G. 1987. Characteristic of the main fault structures. In: Bokov, P., Chemberski, C. (Eds), Geological premises for the hydrocarbon explorations of Northeastern Bulgaria. Tehnika, Sofia, 119-124.

Banks, C.J. 1997. Basins and thrust belts of the Balkan coast of the Black Sea. In: Robinson, A.G. (Ed.), Regional and Petroleum Geology of the Black Sea and Surrounding regions. American Association of Petroleum Geologists, Memoir 68, 115-128.

Bergerat, F., Vangelov, D., Dimov, D. 2010. Brittle deformation, paleostress field reconstruction and tectonic evolution of the Eastern Balkanides (Bulgaria) during Mesozoic and Cenozoic times. In: Sosson, M., Kaymakci, N., Stephenson, R.A., Bergerat, F., Starostenko, V. (Eds), Sedimentary basin tectonics from the Black Sea and Caucasus to the Arabian Platform. Geological Society London, Special Publications 340, 77-111.

Bethke, C.M., Altaner, S.P. 1986. Layer-by-layer mechanism of smectite illitization and application to a new rate law. Clays and Clay Minerals 34, 136-145.

Bokov, P., Georgiev, G., Monahov, I., Atanasov, A., Zhelev, S., Dachev, C., Jordanova, D., Vavilova, M., Nikolova, M., Ognyanov, R. 1987. Tectonic framework. In: Bokov, P., Chemberski, C. (Eds), Geological premises for the hydrocarbon explorations of Northeastern Bulgaria. Tehnika, Sofia, 109-119.

Boles, J.R., Franks, S.G. 1979. Clay diagenesis in Wilcox sandstones of Southwest Texas: implication of smectite diagenesis on sandstone cementation. Journal of Sedimentary Petrology 49, 55-70.
Bončev, E. 1971. Northern boundary of the Forebalkan. In: Bončev, E. (Ed.), Tectonics of the Forebalkan. Publishing House of the Bulgarian Academy of Sciences, Sofia, 51-65 (in Bulgarian, with English summary).

Bončev, E., Belmustakov, E., Jordanov, M., Karaguleva, Y. 1957. Main features in the geological setting of the Forebalkan between Yantra valley and Black Sea. Bulletin de l'Institut de Géologie 5, 3-78 (in Bulgarian, with Russian and German abstracts).

Bruce, C.H. 1984. Smectite dehydration and its relation to structural development and hydrocarbon accumulation in Northern Gulf of Mexico Basin. American Association of Petroleum Geologists Bulletin 68, 673-683.

Burst, J.F. 1959. Post-diagenetic clay mineral environmental relationships in the Gulf Coast Eocene. Clays and Clay Minerals 6, 327-341.

Burst, J.F. 1969. Diagenesis of Gulf Coast clayey sediments and its possible relation to petroleum migration. American Association of Petroleum Geologists Bulletin 53, 73-93.

Burtner, R.L., Warner, M.A. 1986. Relationship between illite/ smectite diagenesis and hydrocarbon generation in Lower Cretaceous Mowry and Skull Creek Shales of the Northern Rocky Mountain area. Clays and Clay Minerals 34, 390-402.

Cercone, K.R., Deming, D., Pollack, H.N. 1996. Insulating effect of coals and black shales in the Appalachian Basin, Western Pennsylvania. Organic Geochemistry 24, 243-249.

Dachev, C., Stanev, V., Bokov, P. 1988. Structure of the Bulgarian Black Sea area. Bullettino di Geofisica Teorica ed Applicata 30, 79-107.

Doglioni, C., Busatta, C., Bolis, G., Marianini, L., Zanella, M. 1996. Structural evolution of the Eastern Balkans (Bulgaria). Marine and Petroleum Geology 13, 225-251.

Dong, H., Peacor, D.R., Freed, R.L. 1997. Phase relations among smectite, R1 illite-smectite, and illite. American Mineralogist 82, 379-391.

Dunoyer de Segonzac, G. 1970. The transformation of clay minerals during diagenesis and low-grade metamorphism: a review. Sedimentology 15, 281-346.

Dypvik, H. 1983. Clay mineral transformations in Tertiary and Mesozoic sediments from North Sea. American Association of Petroleum Geologists Bulletin 67, 160-165.

Eberl, D.D. 1993. Three zones for illite formation during burial diagenesis and metamorphism. Clays and Clay Minerals $41,26-37$.

Eberl, D.D., Hower, J. 1976. Kinetics of illite formation. Geological Society of America Bulletin 87, 1326-1330. 
Eberl, D.D., Środoń, J., Kralik, M., Taylor, B.E., Peterman, Z.E. 1990. Ostwald ripening of clays and metamorphic minerals. Science 248, 474-477.

Elliott, W.C., Aronson, J.L., Matisoff, G., Gautier, D.L. 1991. Kinetics of the smectite to illite transformation in the Denver basin: Clay mineral, $\mathrm{K}-\mathrm{Ar}$, and mathematical model results. American Association of Petroleum Geologists Bulletin 75, 436-462.

Elliott, W.C., Matisoff, G. 1996. Evaluation of kinetic models for the smectite to illite transformation. Clays and Clay Minerals 44, 77-87.

Freed, R.L., Peacor, D.R. 1989. Variability in temperature of the smectite/illite reaction on Gulf Coast sediments. Clay Minerals 24, 171-180.

Georgiev, G. 2012. Geology and hydrocarbon systems in the western Black Sea. Turkish Journal of Earth Sciences 21, 723-754.

Georgiev, G., Dabovski, C. 2001. Mesozoic and Early Cenozoic evolution of the South Moesian platform margin. Proceedings of the $7^{\text {th }}$ Zonenshtain International Conference on Plate Tectonics, Abstracts, 239-240.

Glasmann, J.R., Larter, S., Briedis, N.A., Lundegard, P.A. 1989. Shale diagenesis in the Bergen High area, North Sea. Clays and Clay Minerals 37, 97-112.

Harbury, N. Cohen, M. 1997. Sedimentary History of the Late Jurassic-Paleogene of the Northeast Bulgaria and Bulgarian Black Sea. In: Robinson, A.G. (Ed.), Regional and petroleum geology of the Black Sea and surrounding regions. American Association of Petroleum Geologists, Memoir 68, 129-168.

Hillier, S., Matyas, J., Matter, A., Vasseur, G. 1995. Illite/smectite diagenesis and its variable correlation with vitrinite reflectance in the Pannonian basin. Clays and Clay Minerals 43, 174-183.

Hoffman, J., Hower, J. 1979. Clay mineral assemblages as lowgrade metamorphic geothermometers: Application to the thrust faulted disturbed belt of Montana, USA. In: Scholle, P., Schluger, P. (Eds), Aspects of diagenesis. Society of Economic Paleontologists and Mineralogists, Special Publications 38, 55-79.

Hower, J., Eslinger, E.V., Hower, M.E., Perry, E.A. 1976. Mechanism of burial metamorphism of argillaceous sediment: 1. Mineralogical and chemical evidence. Geological Society of America Bulletin 87, 725-737.

Huang, W.L., Longo, J.M., Pevear, D.R. 1993. An experimentally derived kinetic model for smectite-to-illite conversion and its use as a geothermometer. Clays and Clay Minerals 41, 162-177.

Ivanov, Ž. 1998. Tectonics of Bulgaria. Habilitation thesis, Sofia University “St Kliment Ohridski”, Sofia, 634 pp. (in Bulgarian).

Jacob, H., Kuckelkorn, K. 1977. Das Inkohlungsprofil der Bohrung Miesbach 1 und seine erdölgeologische Interpretation. Erdöl-Erdgas-Zeitschrift 93, 115-124.

Jennings, S., Thompson, G.R. 1986. Diagenesis of Plio-Pleistocene sediments of the Colorado River delta, southern California. Journal of Sedimentary Petrology 56, 89-98.

Johns, W.D., Shimoyama, A. 1972. Clay minerals and petroleum-forming reactions during burial and diagenesis. American Association of Petroleum Geologists Bulletin 56, 2160-2167.

Juranov, S. 1991. Stratigraphy of the Upper Cretaceous series and the Paleogene system in the marine borehole sections at the village of Samotino. Review of the Bulgarian Geological Society 52, 19-29 (in Bulgarian, with English abstract).

Karaguleva, J. 1971. The northern strip of the Forebalkan. In: Bončev, E. (Ed.), Tectonics of the Forebalkan. Publish- ing House of the Bulgarian Academy of Sciences, Sofia, 66-106 (in Bulgarian, with English abstract).

Kânčev, I. 1995. Lower Kamchiya depression. In: Kânčev, I. (Ed.), Explanatory notes to the geological map of Bulgaria 1:100 000, Dolni Chiflik map sheet. Avers ST, Sofia, 84-88 (in Bulgarian).

Kisch, H.J. 1991. Illite crystallinity: recommendations on sample preparation, X-ray diffraction, and interlaboratory samples. Journal of Metamorphic Geology 9, 665-670.

Lahann, R.W. 1980. Smectite diagenesis and sandstone cement: The effect of reaction temperature. Journal of Sedimentary Petrology 50, 755-760.

Libbey, R.B., Longstaffe, F.J., Flemming, R.L. 2013. Clay mineralogy, oxygen isotope geochemistry, and water/rock ratio estimates, Te Mihi Area, Wairakei Geothermal Field, New Zealand. Clays and Clay Minerals 61, 204-217.

Lindgreen, H. 1991. Elemental and structural changes in illite/smectite mixed-layer clay minerals during diagenesis in Kimmeridgian-Volgian (-Ryazanian) clays in Central Trough, North Sea and Norwegian-Danish Basin. Bulletin of the Geological Society of Denmark 39, 1-82.

Lynch, F.L. 1997. Frio shale mineralogy and the stoichiometry of the smectite-to-illite reaction: the most important reaction in clastic sedimentary diagenesis. Clays and Clay Minerals 45, 618-631.

Magara, K. 1975. Reevaluation of montmorillonite dehydration as cause of abnormal pressure and hydrocarbon migration. American Association of Petroleum Geologists Bulletin 59, 292-302.

Mandev, P. 1955. On the Paleogene in Stalin (Varna) region. Annuaire de l'Université de Sofia "St Kliment Ohridski”, Faculté de Biologie, Géologie et Geographie 49 (2), 73-155 (in Bulgarian, with German abstract).

McCarty, D.K., Thompson, G.R. 1991. Burial diagenesis in two Montana Tertiary basins. Clays and Clay Minerals 39, 293-305.

Morse, J.W., Casey, W.H. 1988. Ostwald processes and mineral paragenesis in sediments. American Journal of Science 288, 537-560.

Nadeau, P.H., Reynolds, R.C. 1981. Burial and contact metamorphism in the Mancos shale. Clays and Clay Minerals 29, 249-259.

Nadeau, P.H., Wilson, M.J., McHardy, W.J., Tait, J.M. 1985. The conversion of smectite to illite during diagenesis: evidence from some illitic clays from bentonites and sandstones. Mineralogical Magazine 49, 393-400.

Pearson, M.J., Small J.S. 1988. Illite-smectite diagenesis and palaeotemperatures in northern North Sea Quaternary to Mesozoic shale sequence. Clay Minerals 23, 109-123.

Perry, E.A., Hower, J. 1970. Burial diagenesis in the Gulf Coast pelitic sediments. Clays and Clay Minerals 18, 165-177.

Pollack, H.N., Cercone, K.R. 1994. Anomalous thermal maturities caused by carbonaceous sediments. Basin Research 6, $47-51$.

Pollastro, R.M. 1990. The illite/smectite geothermometer concepts, methodology, and application to basin history and hydrocarbon generation. In: Nuccio, V.F., Barker, C.E. (Eds), Applications of thermal maturity studies to energy exploration. Society of Economic Paleontologists and Mineralogists, Rocky Mountain Section, 1-18.

Pollastro, R.M. 1993. Consideration and application of the illite/smectite geothermometer in hydrocarbon-bearing rocks of Miocene to Mississippian age. Clays and Clay Minerals 41, 119-133.

Powers, M. 1967. Fluid-release mechanisms in compacting marine mudrocks and their importance in oil exploration. American Association of Petroleum Geologists Bulletin 51, $1240-1254$. 
Pytte, A.M., Reynolds, R.C. 1989. The thermal transformation of smectite to illite. In: Naeser, N.D., McColloh, T.H. (Eds), Thermal history of sedimentary basins. SpringerVerlag, New York, 133-140.

Ramseyer, K., Boles, J.K. 1986. Mixed-layer illite/smectite minerals in Tertiary sandstones and shales, San Joaquin Basin, California. Clays and Clay Minerals 34, 115-124.

Reynolds, R.C., Hower, J. 1970. The nature of interlayering in mixed-layer illite-montmorillonites. Clays and Clay Minerals 18, 25-36.

Rice, D.D., Claypool, G.M. 1981. Generation, accumulation, and resource potential of biogenic gas. American Association of Petroleum Geologists Bulletin 64, 5-25.

Robert, P. 1988. Organic metamorphism and geothermal history. Elf-Aquitaine and D. Reidel, Dordrecht, $311 \mathrm{pp}$.

Rybach, L. 1984. The paleogeothermal conditions of the Swiss Molasse Basin: Implication to hydrocarbon potential. Revue de l'Institut Français du Pétrole 39, 143-146.

Rybach, L., Bodmer, P. 1980. Die geothermischen Verhältnisse der Schweizer Geotraverse im Abschnitt Basel-Luzern. Eclogae Geologicae Helvetiae 73, 501-512.

Schegg, R. 1994. The coalification profile of the well Weggis (Subalpine Molasse, Central Switzerland: Implication for erosion estimates and the paleogeothernal regime in the external part of the Alps. Bulletin der Vereinigung Schweiz Petroleum-Geologen und -Ingenieure 61, 57-67.

Schegg, R., W. Leu. 1996. Clay mineral diagenesis and thermal history of the Thonex well, Western Swiss Molasse Basin. Clays and Clay Minerals 44, 693-705.

Sinclair, H.D., Juranov, S.G., Georgiev, G., Byrne, P., Mountney, N.P. 1997. The Balkan Thrust Wedge and Foreland Basin of Eastern Bulgaria: Structural and Stratigraphic development. In: Robinson, A.G. (Ed.), Regional and petroleum geology of the Black Sea and surrounding regions. American Association of Petroleum Geologists, Memoir 68, 91-114.

Środoń, J. 1980. Precise identification of illite/smectite interstratifications by X-ray powder diffraction. Clays and Clay Minerals 28, 401-411.

Środoń, J. 1981. X-ray identification of randomly interstratified illite/smectite in mixtures with discrete illite. Clay Minerals 16, 297-304.

Środoń, J. 1984a. Mixed-layer illite-smectite in low-temperature diagenesis: Data from the Miocene of the Carpathian foredeep. Clay Minerals 19, 205-215.

Środoń, J. 1984b. X-ray powder diffraction identification of illitic materials. Clays and Clay minerals 32, 337-349.

Środoń, J., Eberl, D.D. 1984. Illite. In: Bailey, S.W. (Ed.), Micas. Reviews in Mineralogy 13. Mineralogical Society of America, Washington, 495-544.

Steiner, A. 1968. Clay minerals in hydrothermally altered rocks at Wairakei, New Zealand. Clays and Clay Minerals 16, 193-213.

Stoykova, K. 1994. Nannofossil biostratigraphy of the wells in the Black Sea offshore around the villages of Samotino and Shkorpilovtsi. Review of the Bulgarian Geological Society 55, 69-82 (in Bulgarian, with English abstract).

Tari, G., Dicea, O., Faulkerson, J., Georgiev, G., Popov, S., Stefanescu, M., Weir, G. 1997. Cimmerian and Alpine stratigraphy and structural evolution of the Moesian platform (Romania/Bulgaria). In: Robinson, A.G. (Ed.), Regional and petroleum geology of the Black Sea and surrounding regions. American Association of Petroleum Geologists, Memoir 68, 63-90.

Teichmüller, R., Teichmüller, M. 1986. Relations between coalification and palaeogeothermics in Variscan and Alpidic foredeeps of Western Europe. In: Buntebarth, G., Stegena, L. (Eds), Palaeogeothermics. Lecture Notes in Earth Sciences 5.. Springer-Verlag, Berlin-Heidelberg-New York-London-Paris-Tokyo, 53-78.

Tissot, B.P., Welte, D.H. 1984. Petroleum formation and occurrence. Springer-Verlag, Berlin, 539 pp.

Tomita, K., Takahashi, H., Watanabe, T. 1988. Quantification curves for mica/smectite interstratifications by X-ray powder diffraction. Clays and Clay Minerals 36, 258-262.

Towe, K.M. 1962. Clay mineral diagenesis as a possible source of silica cement in sedimentary rocks. Journal of Sedimentary Petrology 32, 26-28.

Uysal, T.I., Golding, S.D., Audsley, F. 2000. Clay-mineral authigenesis in the Late Permian coal measures, Bowen Basin, Queensland, Australia. Clays and Clay Minerals 48, 351-365.

Vangelov, D. 2000. Stratigraphic aspects of the basin analysis. An example from the Upper Cretaceous-Paleogene sedimentary record of the Eastern Balkanides and adjacent terrains. PhD thesis, Sofia University "St Kliment Ohridski”, Sofia, 40 pp (in Bulgarian).

Vangelov, D. 2002. Chudnite skali dislocation characteristics in the East Balkans coastal part. Annuaire de l'Université de Sofia "St Kliment Ohridski", Faculté de Géologie et Géographie 95 (1), 55-65 (in Bulgarian, with English abstract).

Varajao, A., Meunier, A. 1995. Particle morphological evolution during the conversion of illite/smectite to illite in Lower Cretaceous shales from Sergipe-Alagoas basin, Brazil. Clays and Clay Minerals 43, 14-28.

Varajao, A., Meunier, A. 1996. Burial and thermal conditions of diagenesis in the Lower Cretaceous Barra de Itiuba Shale Formation, Sergipe-Alagoas Basin, Brazil. Bulletin de la Société Géologique de France 167, 597-607.

Vazquez, M., Nieto, F., Morata, D., Droguett, B., CarrilloRosua, F., Morales, S. 2014. Evolution of clay mineral assemblages in the Tinguiririca geothermal field, Andean Cordillera of central Chile: an XRD and HRTEM-AEM study. Journal of Volcanology and Geothermal Research 282, 43-59.

Velde, B., Iijima, A. 1988. Comparison of clay and zeolite mineral occurrences in Neogene age sediments from several deep wells. Clays and Clay Minerals 36, 337-342.

Velde, B., Espitalié, J. 1989. Comparison of kerogen maturation and illite/smectite composition in diagenesis. Journal of Petroleum Geology 12, 103-110.

Velde, B., Vasseur, G. 1992. Estimation of the diagenetic smectite to illite transformation in time-temperature space. American Mineralogist 77, 967-976.

Velde, B., Suzuki, T., Nicot, E. 1986. Pressure-temperaturecomposition of illite/smectite mixed-layer minerals: Niger delta mudstones and other examples. Clays and Clay Minerals 34, 435-441.

Weaver, C.E., Beck, K.C. 1971. Clay water diagenesis during burial: How mud becomes gneiss. Geological Society of America, Special Paper 134, 96 pp.

Yaranov, D. 1960. Tectonics of Bulgaria. Tehnika, Sofia, 282 pp. 